University of Wollongong

Research Online

Faculty of Business - Papers (Archive)

Faculty of Business and Law

$1-1-2015$

The microstructure of Australian takeover announcements

Martin Bugeja

University of Technology Sydney

Vinay Patel

University of Technology Sydney

Terry S. Walter

University of Sydney, twalter@uow.edu.au

Follow this and additional works at: https://ro.uow.edu.au/buspapers

Part of the Business Commons

Research Online is the open access institutional repository for the University of Wollongong. For further information contact the UOW Library: research-pubs@uow.edu.au 


\title{
The microstructure of Australian takeover announcements
}

\author{
Abstract \\ Using several microstructure variables, this study provides an intra-day examination of aggressive trading \\ around Australian takeover announcements. We conduct this analysis for both target and bidding firms. \\ We examine aggressive trading (i.e. by those who initiate the trade) using the abnormal behaviour of \\ returns, trading volume, volatility and time-weighted spreads and depth. In addition, we develop a novel \\ profit/loss measure (PLM) based on trade initiation and provide new evidence using the recently \\ developed volume-synchronised probability of informed trading (VPIN) metric. In a univariate setting, \\ these measures provide evidence of increased aggressive trading in Australian target firms. Further, after \\ controlling for several microstructure variables, multivariate analysis reveals the presence of abnormally \\ elevated time-weighted spreads prior to the announcement date for target firms. We show that VPIN is \\ significantly elevated for target firms, especially in the four days prior to the takeover announcement.

\section{Disciplines} \\ Business \\ Publication Details \\ Bugeja, M., Patel, V. \& Walter, T. (2015). The microstructure of Australian takeover announcements. \\ Australian Journal of Management, 40 (1), 161-188.
}




\title{
The Microstructure of Australian Takeover Announcements
}

\author{
Martin Bugeja a , Vinay Patel ${ }^{\mathrm{b}}$ and Terry Walter \\ ${ }^{a}$ School of Accounting, University of Technology, PO Box 123, Broadway, NSW, 2007, Australia \\ Email Martin.Bugeja@uts.edu.au, Phone +61 29514 3743, Fax +61 295143669 \\ ${ }^{\text {b }}$ School of Finance, University of Technology, Sydney, PO Box 123, Broadway, NSW, 2007, Australia \\ Email vinay_patel_01@ hotmail.com, Phone +6129514 4022, Fax 61295147722 \\ ${ }^{\mathbf{c}}$ Corresponding author, School of Finance, University of Technology, Sydney, PO Box 123, Broadway, \\ NSW, 2007, Australia \\ Email Terry.Walter@uts.edu.au, Phone +61 29514 3860, Fax +61 295147722
}

\begin{abstract}
This study examines the behaviour of returns, trading volume, volatility, liquidity and a unique informed trading metric around takeover announcements for both target and acquiring firms, to determine whether informed trading is prevalent within the Australia market. Using intraday data, we find direct and indirect evidence of informed trading. For target firms abnormal returns and volume, widened spreads and increased purchases of target firm shares are observed during the period prior to the takeover announcement. In addition regression analysis finds a statistically significant relationship between abnormal returns and our cumulative informed trading metric. Informed trading is evident within almost $20 \%$ of sample target firms, irrespective of whether the bidder is involved in a toehold acquisition. Limited evidence of informed trading is also observed for acquiring firms through negative returns, abnormal volume, widened spreads and selling of the acquiring firm shares prior to the takeover announcement.
\end{abstract}

Keywords: Microstructure, takeover announcement, informed, target, bidder

JEL Classifications G14, G34 


\section{Introduction}

This study examines the microstructure of takeover announcements in Australia in order to determine whether informed trading is prevalent within both target and acquiring firms. We define an informed trade as a buyer initiated trade that makes a profit (i.e., the market-adjusted reference price after the trade is higher than the purchase price) or a seller initiated trade where market-adjusted reference prices subsequent to the trade are lower. Evidence of informed trading suggests increased levels of information asymmetry between investors, and perhaps warrants a regulatory response.

Takeover announcements are major economic events which have significant wealth implications for the involved parties. The takeovers we study have a total market value of approximately $\$ 200$ billion (or approximately $17 \%$ of the total market capitalization of ASX-listed stocks), with each deal worth an average of approximately $\$ 1$ billion. The economic significance of these takeovers illustrates the importance of determining whether informed investors are present. In addition, the results of this study are important for other participants (in particular hedge fund arbitrageurs) who trade around takeover announcements in assessing the likely outcome of their trading. Further, evidence of announcement returns will provide valuable information to bidding firms to gauge whether they should continue with or withdraw from a bid.

Australian insider trading provisions are documented in Part 7.10, Division 3 of the Corporations Act 2001. Specifically, sections 1043A(1) and (2) state that "if a person possesses inside information then the insider must not acquire or dispose of relevant financial products. Further, the insider must not communicate this information with another individual or procure another individual to acquire or dispose of relevant financial products." On the $20^{\text {th }}$ of November 2003 the Corporations and Markets Advisory Committee (CAMAC (2003)) provided 38 recommendations to the Australian Government in an attempt to improve insider trading regulation. Particular recommendations which were accepted by the Government include; increasing disclosure requirements for directors, reducing the number of exemptions for directors and white knights of target firms and a widening of the definition of informed trading. This CAMAC research provided the most recent update to insider trading regulations in Australia. It should be noted that our study focuses on informed trading which is not necessarily indicative of illegal insider trading.

Our results document significant positive levels of returns, volume, volatility, bid ask spreads and purchases of target firm shares during the pre announcement period, which provides indirect evidence of informed trading. The abnormal behaviour observed for these metrics increases dramatically on the announcement date as investors trade on news of the takeover announcement. During the post announcement period the behaviour of these metrics diminishes as news of the takeover bid becomes 
efficiently incorporated into the target firm's share price. For acquiring firms limited indirect evidence of informed trading is found in abnormal decreases in returns, increases in volume, widened spreads and increased selling of acquiring firm shares prior to the takeover announcement. On the announcement date we observe significant negative abnormal returns, positive volume, widened spreads and increased liquidity.

Examination of a unique informed trading metric suggests that on average investors who trade in either the target or acquiring firm around the takeover announcement incur losses. However, further analysis finds a significantly positive relationship between cumulative pre bid abnormal returns and the cumulative informed trading metric for targets. Evidence of significant informed trading is found in approximately $20 \%$ of sample target firms. Holistically, there is some evidence of informed trading in the Australian market.

The remainder of the paper is as follows. Section 2 provides a review of related U.S. and Australian literature. Section 3 details the selection of sample target and acquiring firms. Section 4 provides descriptive statistics of sample firms. Section 5 describes the methodology while Section 6 presents the empirical results of this study. Lastly, Section 7 provides concluding remarks.

\section{Prior Literature}

\subsection{U.S. Literature}

The subject of informed trading around takeover announcements has been widely researched for target firms in the United States. In comparison, there exist only a limited number of papers which examine this issue for acquiring firms. This literature analyses the behaviour of several metrics including changes in returns, volume, bid ask spreads, adverse selection costs and market depth for both target and acquiring firms in the period prior to the announcement date. For target firms an increase in returns and volume, widened bid asks spreads (as a result of increased adverse selection costs) and reduced market depth prior to a takeover announcement suggest the existence of informed trading. The literature conclusively finds that returns and volumes increase in the pre announcement period for target firms. However, mixed results are found in relation to the behaviour of the bid ask spread, adverse selection costs and market depth for target firms.

\subsubsection{Returns and Trading Volume}

Keown and Pinkerton (1981) provide early evidence to suggest that informed trading occurs in target firms up to 12 days prior to the public announcement of a takeover and that almost half of the market reaction to a takeover occurs before the public announcement. Meulbroek (1992) examines insider trading 
around takeover announcements using data from the SEC on illegal insider trading for U.S. targets between 1980 and 1989. She finds that abnormal returns on days where insider trading occurred averaged $3.06 \%$ for the entire sample. During the 20 days leading up to the takeover announcement $43 \%$ of the pre announcement price movement occurred on the 2.5 days in which insider trading was evident. Further, Meulbroek (1992) finds abnormal levels of trade volume on days in which insider trading occurred.

Eyssell and Arshadi (1993) analyse trading of target firms shares prior to takeover announcements to determine whether the observed run-up can be attributed to registered insiders, informed outsiders or trend chasers. The authors find a statistically positive relationship between abnormal returns and volume, and abnormal volume and net insider purchases during the -25 to 0 day period before the takeover announcement.

Jensen and Ruback's (1983) literature review documents abnormal returns for targets of $16 \%$ to $30 \%$ in 13 U.S. studies conducted using data prior to 1980. Sanders and Zdanowicz (1992) find additional evidence to suggest that the pre bid run-up observed in target firms prior to takeover announcements is due to informed trading. In contrast, Jarrell and Poulsen (1989) analyse target firms listed on the NYSE or AMEX and find that increased returns and volume during the pre announcement period can be attributed to market speculation, and not informed trading. Further, the authors consider other bid characteristics including whether the bid was anticipated in the media, toehold acquisition by the bidder and whether the bid was hostile or friendly, to determine whether these characteristics affect pre bid run-up in stock prices. The authors find that approximately $40 \%$ of the eventual takeover premium is anticipated in the pre bid run-up, primarily due to media speculation. The authors suggest that the results imply that increased returns and volume prior to the announcement are associated with a "legitimate market for information".

\subsubsection{Spreads}

A substantial previous literature shows both theoretically and empirically that the bid ask spread in U.S. dealer markets can be decomposed into three components; order processing costs, inventory holding costs and adverse selection costs. More importantly, these papers have documented that dealers protect themselves from incurring losses from trading with informed traders by increasing the adverse selection component of the bid ask spread.

Glosten and Harris (1988) develop a model which estimates the components of the bid ask spread. The authors confirm predictions of asymmetric information theory as they find that the adverse selection component of the spread is positive. Consistent with Copeland and Galai (1983), Glosten and Harris find that market makers increase the bid ask spread when they are dealing with informed traders. 
Lin, et al. (1995) and Huang and Stoll (1997) also develop spread decomposition models. ${ }^{1}$ Their research is linked to Easley and O'Hara (1987) which finds that larger trades are associated with increased adverse selection costs. Further, the authors show that larger trades are made by informed traders. This result means that market makers must take trade size into account when determining the bid ask spread.

Huang and Stoll (1997) develop yet another bid ask spread decomposition model which separates the spread into order processing, inventory holding and adverse selection components. The adverse selection cost is found to be larger for small/medium trades rather than large trades. This relationship is also shown by George, et al. (1991). The implication is that informed traders split their orders in an attempt to hide their trades with other noise trades.

\subsubsection{Intraday Patterns in Bid Ask Spreads}

McInish and Wood (1992) analyse intraday patterns in time weighted bid ask spreads for NYSE stocks. They find that spreads exhibit a "crude reverse J shaped" pattern over the trading day, i.e., spreads are higher at the start and end of the day.Brock and Kleidon (1992) examine the bid ask spread, minute by minute, for 462 stocks listed on the NYSE between the $1^{\text {st }}$ and $15^{\text {th }}$ of October 1987. The authors find increased demand and decreased elasticity for transactions at the beginning and end of the trading day and as a result provide evidence supporting the "U shaped" intraday pattern in spreads predicted by Foster and Vishwanathan (1993)'s model.

\subsubsection{Market Microstructure}

There have been numerous studies which focus on market microstructure metrics of target firms around takeover announcements. These studies generally use daily measures around takeover announcements. In contrast, we use intra-day observation periods.

Foster and Vishwanathan (1995) examine the behaviour of order flow, quoted bid ask spreads, depth and adverse selection costs for target firms around tender offers. They find that after the takeover announcement average transaction size increases, the number of transactions increases and that a large percentage of trades are seller initiated. These findings support the notion that information asymmetry between investors has reduced. The authors also find that the quoted spread decreases and quoted depth increases in the post announcement period. Evidence of larger spreads and reduced depth in the pre announcement period suggests the existence of informed trading prior to takeover announcements.

However, in stark contrast to the results documented by Foster and Vishwanathan (1995), a number of studies find conflicting evidence regarding informed trading around takeover announcements. Jennings

\footnotetext{
${ }^{1}$ Other spread decomposition models include Stoll (1989) and Kim and Ogden (1996).
} 
(1994) analyses changes in target firms' returns, volumes, bid-ask spreads, quote size and the components of the bid-ask spread surrounding takeover announcements from an intraday perspective. The results reveal that most of the increased returns occur after the public announcement of a takeover. Further, Jennings (1994) finds little evidence to suggest that spreads widen and quote sizes decrease before takeover announcements.

Conrad and Niden (1992) use a sample of NYSE target firms to analyse the adverse selection component of the bid ask spread. The results show that trading volume increases in the pre announcement period, however this volume appears to be driven by an increase in the number of transactions and not by larger trades. The results indicate that during normal trading changes in order size are positively related to changes in spreads, which is consistent with Easley and O'Hara's (1987) findings, however the authors do not find any evidence of increased adverse selection costs around the acquisition announcement.

Ascioglu, et al. (2002) examine returns, volumes, bid ask spreads and adverse selection costs around merger announcements for firms trading on the NYSE and NASDAQ. The authors find abnormal returns and volumes in the four days before the announcement. However, the bid ask spread does not widen and there is an insignificant change in adverse selection costs prior to the merger announcement. Kryzanowski and Lazrak (2007) examine the behaviour of returns, volumes, volatility, bid ask spreads, adverse selection costs and depths for both target and acquiring firms around tender offers. Additionally, the authors use a model developed by Easley, et al. (1996) to estimate the level of trading intensity, which allows the probability of informed trading during the event period to be estimated. The authors find that spreads decrease, depth increases and trading volume increases from the pre announcement to announcement period for both NYSE and NASDAQ listed target firms. Using spread decomposition models developed by Glosten and Harris (1988) and Lin, et al. (1995), the authors find that the adverse selection component of the spread decreases in the announcement period for target firms. Lastly, the authors demonstrate increased trading intensity of uninformed traders relative to informed traders prior to the announcement period for target firms and these results suggest a reduced probability of informed trading during this period.

In summary, the literature thus far conclusively finds that increased returns and volumes are observed prior to the announcement of a takeover bid. However, mixed evidence is found in regards to behaviour of the bid ask spread, adverse selection costs and depth during the same period. It should be noted however, that most of these studies use daily, rather than intraday, data.

In contrast to target firms, there exists a dearth of literature which analyses the behaviour of returns, volume and microstructure of acquiring firms around takeover announcements.

Draper and Paudyal (1999) analyse returns, trading activity and spreads for acquiring firms and find significant negative abnormal returns, though only to the announcement date. Volume and the number of 
transactions increase on the announcement date, while these decrease between +2 and +4 days after the announcement. Kryzanowski and Lazrak (2007) find contrasting results in the behaviour of several metrics for acquiring firms. Similar to the target firms within their study, spreads decrease, depth increases and volume increases, however the magnitude of these changes is reduced between the pre announcement and announcement periods. Further, the authors find no significant change in adverse selection costs or heightened probability of informed trading for acquiring firms prior to the announcement date.

Lipson and Mortal (2006) focus on abnormal changes in liquidity for 463 acquiring firms between 1993 and 2003. Particular metrics the authors use to measure liquidity include; quoted and effective spreads, quoted depth, depth as measured by Kyle $(1985)^{2}$ and adverse selection costs as measured by a model developed by Madhavan, et al (1987). The results show that from the pre to the post announcement periods all four spread measures significantly decrease, quoted depth increases, adverse selection costs decrease and trading volume (measured by volume and the number of trades) increases, which indicates an increase in liquidity after the takeover announcement.

Cumming and $\mathrm{Li}$ (2010) analyse the impact of takeover announcements on acquiring firms involved in public and private acquisitions, whilst taking into account several firm-specific factors, including Tobin's Q, stock as a method of payment, foreign targets and venture capital based targets. Acquiring firms which have the following characteristics are found to have a negative run-up CAR;- large Tobin Q, higher levels of information asymmetry, the use of equity as a method of payment and the acquisition of foreign target firms -. In contrast, run-up CAR increases when acquiring firms purchase target firms backed by venture capital.

\subsection{Australian Literature}

In contrast to the U.S., there has been limited study of informed trading aroundAustralian takeover announcements. Most prior research focuses on abnormal behavior of returns and volume in target and acquiring firms.

\subsubsection{Returns and Trading Volume}

Dodd (1976) uses monthly data to examine the returns to shareholders of acquiring and target firms around takeover announcements. In the month prior to the announcement target firms experience an abnormal return of $25 \%$. Also, positive CARs are found in the two months after the takeover announcement. Further, acquiring firms experience positive abnormal returns prior to the takeover announcement. However, in the 24 months after the announcement acquirers whose bids are successful

\footnotetext{
${ }^{2}$ Kyle (1985) uses a measure of depth which indicates the extent to which prices change as a result of changes in order flow. Thus, an increase in this depth measure signals a decrease in market depth.
} 
(unsuccessful) bids have CARs of -10.9\% (0\%). Walter (1984) and Casey, et al. (1987) document similar target firm results. Walter (1984) and Brown and da Silva Rosa (1998) offer explanations for the anomalous acquirer post-takeover drift identified in Dodd (1976).

Murray (1994) examines the share price run-up and abnormal trading volume prior to takeover announcements. He finds significant returns and trading volume in firms which had takeover related news in the pre announcement period, which suggests that it is market speculation and not insider trading that is the cause of this observed behaviour.

Clarkson, et al. (2006) provide a unique examination of the market reaction to takeover rumours posted on the Hotcopper internet discussion site. Using intraday analysis the authors find abnormal returns and volume during the 10 minute window in which the rumour is posted. Additionally, abnormal volume is observed in the previous 10 minute interval.

\section{Sample and Data Selection}

We study takeover announcements between the $1^{\text {st }}$ of January 1997 and the $31^{\text {st }}$ of December 2009 which meet the following criteria. First, only deals which are valued at greater than $\$ 100$ million extracted from the Connect 4 Takeovers database are included. This results in an initial sample of 460 deals. Second, if the takeover was a scheme then these deals are excluded from the sample, which reduces the sample to 299 takeover announcements. Further, only deals in which either the target or acquiring firm is listed on the Australian Stock Exchange (ASX) are included in the final sample. This requirement reduces the sample to 299 target firms and 146 bidding firms. We focus on takeover announcements which are not anticipated by the market. Thus, deals in which there is a toehold of greater than $50 \%$ and deals where there was a bid in the previous six months are also removed from the sample. This results in a final sample of 195 target firms ${ }^{3}$ and 137 acquiring firms. All intraday data examined for each metric studied in this paper is provided by the Securities Industry Research Centre of Asia-Pacific Limited (SIRCA).

\section{Descriptive Statistics}

Descriptive statistics for sample target and acquiring firms are detailed in Table I. On average acquiring firms pay $\$ 1,068 \mathrm{~m}$ for target firms. The aggregate deal value is approximately $\$ 200$ billion. This fact and the substantial costs incurred by acquiring firms during the takeover process highlight the importance of this study in determining whether informed trading is taking place. The average market

\footnotetext{
${ }^{3} \mathrm{We}$ also examine a sub-sample of targets in which we eliminate those targets where the bidder acquired any toehold in the target. This "no toehold" sub-sample contains 141 targets.
} 
capitalization of acquiring firms is approximately 2.11 times the size of sample target firms and highlights the relative difficulty of observing the effects of a takeover for the acquiring firm.

In addition Table I displays that an average premium of $29.62 \%$ is offered. Only 19 deals involved the target firm being offered a negative premium. A negative premium is unlikely to result in a successful bid, unless it conveys information not previously known to the market. In five cases a premium of greater than $100 \%$ was offered to the target firm.

\section{Table I}

\section{Descriptive Statistics for sample target and acquiring firms between 1997 and 2009}

Table I presents descriptive statistics for 195 target firms and 137 acquiring firms which were involved in unanticipated takeover bids. All values are reported in \$A million, except Premium and Toehold. Deal Value is the effective offer price of the takeover bid multiplied by shares outstanding in the target firm on the announcement date of the takeover. Target Net Assets is the difference between the Total Assets and Total Liabilities of the target firm as reported in the annual report prior to the takeover bid. Target NPAT is the Net Profit after tax as reported by the target firm in the annual report prior to the takeover bid. Target Market Capitalisation is the number of shares issued in the target firm multiplied by the target firm share price on the announcement date of the annual report prior to the takeover bid. Acquirer Net Assets is the difference between the Total Assets and Total Liabilities of the acquirer firm as reported in the annual report prior to the takeover bid. Acquirer NPAT is the Net Profit after tax as reported by the acquirer firm in the annual report prior to the takeover bid. Acquirer Market Capitalisation is the number of shares issued in the acquirer firm multiplied by the acquirer firm share price on the announcement date of the annual report prior to the takeover bid. Premium is the percentage difference between the effective offer price and target firm share price 20 trading days prior to the takeover announcement. Toehold is the number of shares held by the acquiring firm divided by shares outstanding in the target firm.

\begin{tabular}{ccccccc}
\hline Statistic & Mean & Median & Min. & $\mathbf{2 5 \%}$ & $\mathbf{7 5 \%}$ & Max. \\
\hline Deal Value & $\$ 1,068.386$ & $\$ 298.501$ & $\$ 100.895$ & $\$ 170.712$ & $\$ 709.815$ & $\$ 17,229.904$ \\
Target NA & $\$ 421.647$ & $\$ 151.231$ & $\$ 5.057$ & $\$ 66.891$ & $\$ 367.905$ & $\$ 6,969.256$ \\
Target NPAT & $\$ 31.625$ & $\$ 10.170$ & $(\$ 628.600)$ & $\$ 1.067$ & $\$ 34.417$ & $\$ 743.600$ \\
Target Mkt Cap. & $\$ 891.431$ & $\$ 234.843$ & $\$ 11.760$ & $\$ 120.715$ & $\$ 497.804$ & $\$ 24,984.162$ \\
Acquirer NA & $\$ 1,729.520$ & $\$ 541.461$ & $\$ 0.211$ & $\$ 138.578$ & $\$ 1,224.209$ & $\$ 29,377.000$ \\
Acquirer NPAT & $\$ 232.878$ & $\$ 48.070$ & $(\$ 646.000)$ & $\$ 6.779$ & $\$ 141.491$ & $\$ 3,692.000$ \\
Acquirer Mkt & $\$ 1,881.535$ & $\$ 814.153$ & $\$ 9.554$ & $\$ 250.160$ & $\$ 2,032.122$ & $\$ 34,702.875$ \\
Cap. & $29.62 \%$ & $25.48 \%$ & $(19.79 \%)$ & $12.68 \%$ & $38.25 \%$ & $261.39 \%$ \\
Premium offered & $10.70 \%$ & $9.83 \%$ & $0.00 \%$ & $0.00 \%$ & $19.78 \%$ & $48.76 \%$ \\
\hline Toehold & & & & &
\end{tabular}


Another Australian study conducted by Duong and Izan (2008) which examines all bids occurring between 1980 and 2004 calculates a premium of $21.05 \%$ (25.81\%) when using a share price one (two) months before the takeover announcement. Our results are similar. A number of other studies in the U.S. examine the premium offered to target firms. Bradley (1980), Jarrell, et al. (1988) and Cotter and Zenner (1994) analyse premiums for 30 and 41 days prior to the takeover announcement and calculate a premium of $47 \%$ to $53 \%$. Jennings and Mazzeo (1993) document a premium of 23\% calculated using prices 10 days prior to the announcement. Further, Betton and Eckbo (2000) calculate premiums for single (multiple) bids 60 days prior to the announcement date of $51 \%$ (45\%). Generally, these results indicate that a higher premium is offered in the U.S. when compared to Australian bids.

Additionally, Table I shows that on average the size of the toehold for sample acquiring firms is $10.7 \%$. In this study takeovers where the acquiring firm had a toehold greater than $50 \%$ were discarded in order to focus on the impact of unpredictable bids. Firms with large toeholds are likely to be making "mop up" bids, which are somewhat predictable, to secure the remaining shares of a target firm. Other U.S. studies, Betton and Eckbo (2000) and Bradley, et al. (1988) report a toehold of $14.57 \%$ and $10 \%$ respectively. In comparison this suggests that on average Australian acquiring firms have a similar toehold in the target firm before issuing their takeover bid.

\section{Methodology}

In order to determine the existence of informed trading in the Australian market we examine the intraday behaviour of several metrics ${ }^{4}$ that measure returns, volumes, volatility, spreads, liquidity and an informed trading measure. This study uses intraday timing as implemented by Chiyachantana, et al. (2004) in their study of information asymmetry around earnings announcements before and after the introduction of Regulation Fair Disclosure. According to Jennings (1994) an intraday analysis of such metrics allows for more accurate inferences to be made regarding the anticipation, arrival and dissemination of information in the marketplace.

\footnotetext{
${ }^{4}$ The metrics we use were developed by Securities Markets Research and Training Statistics (i.e., SMARTS Limited, and their use is subject to copyright.
} 


\subsection{Periods of Interest: Event period and Control period}

Chiyachantana et al (2004) use three periods in their earnings study: the benchmark period, preannouncement period and event period. Each period comprises 26 half hour intervals. The benchmark period occurs 14 days prior to the earnings announcement, the pre announcement period occurs two days before the earnings announcement and the event period continues for two days from the earnings announcement.

This study adopts a similar approach and considers an event period which consists of a pre announcement period, announcement date and post announcement period and compares these to a control period for each takeover announcement. The event period for each takeover announcement is a 21 day period. Within the event period the pre announcement period lasts for ten days prior to the takeover announcement and the post announcement period lasts for ten days after the takeover announcement.

This study implements intraday timing by segmenting each trading day into three two hourly intervals. In the event period there are 63 two hourly intervals in total. The pre announcement period comprises 30 two hourly intervals $(-30, \ldots,-1)$, the announcement period comprises three two hourly intervals $(0,+1,+2)$ and the post announcement period comprises 30 two hourly intervals $(+3, \ldots,+32)$.

The calculation of the metrics used within this study exclude trades that occurred during the opening and closing auction of each trading day, because the identity of the trade initiator cannot be determined in these auctions. Chiyachantana et al (2004) do not control for day of the week patterns in their study, hence potentially causing a day of the week bias. To overcome this potential bias we ensure that the same days of the week are represented within the pre announcement period, post announcement period and control period. Thus, in the pre and post announcement periods each day of the week is represented twice allowing us to examine patterns without day of the week influencing the results. The control period used is a ten week period from -13 to -3 weeks prior to the event period. For each two hourly interval (63 in total) during the event period there is a control interval which is the average of ten corresponding two hourly intervals during the ten week control period. Thus each stock is used as its own control in isolating abnormal behaviour in the studied metrics. Further, if one of the control dates happens to be a public holiday then this day is excluded and the same day from the previous week is used i.e., week -14. If there is more than one missing date in the control period on the same trading day, then week -15 for that day is used, and so forth.

A bootstrapped control and event period distribution is generated in order to test the abnormal behaviour of the metrics examined. The distributions are estimated using 1,000 observations. Each of 
these distributions is created using random sampling with replacement. A t-statistic test $t^{5}$ is used to test for the differences in the means of the event and control period bootstrapped distributions.

In addition and as a robustness measure an additional t-statistic test is conducted on the difference between the average event period and average control period values (averaged over the $\mathrm{N}$ sample firms) to examine the abnormal behaviour of each metric during all 63 intervals during the event period.

\subsection{Returns Metrics}

Two price metrics are used to calculate returns for the target and acquiring firms around takeover announcements.

1. Volume weighted average price (VWAP)

$$
V_{W A P_{k}}=\sum_{k=1}^{n}\left(\text { TradePrice }_{k} \text { TradeVolume }_{k}\right) / n
$$

2. Time weighted midpoint price $(T W M P)$

$$
\operatorname{TWMP}_{k}=\sum_{k=1}^{n} \text { MidpointPrice }_{k} \text { Time }_{k} / \sum_{k=1}^{n} \text { Time }_{k}
$$

The return for each interval in the event period is calculated as the natural logarithm of the price in one interval (i.e., either the VWAP or the TWMP) divided by the price in the previous interval. Abnormal returns are equal to event period returns less the return in the corresponding control period.

The following criteria apply to the calculation of these two return metrics, as well the volume, volatility and liquidity metrics. These metrics are calculated for each stock for the 63 two hourly intervals during the event period and during the ten week control period. In the event that for example VWAP returns does not exist for all 10 weeks during the control period, the control period VWAP return is calculated as the average over the 'N' existing observations. Similarly, if VWAP return does not exist for a particular interval in the event period then this metric is not calculated for these specific intervals.

\subsection{Volume Metrics}

We calculate the total volume, total value of trading, the number of trades and the average trade size for target and acquiring firms in each of the 63 event periods. Each event period is compared to the control period to determine whether there is abnormal behaviour in these four volume metrics.

\footnotetext{
${ }^{5}$ This test is conducted under the assumption that the bootstrapped control and event period distributions generated are normally distributed, as a result of the large number of observations used to create them. As an additional robustness measure a Wilcoxon Rank Sum Test is also conducted to test the abnormal behaviour of each metric. This test makes no assumption about the shape of the distributions generated from bootstrapping.
} 


\subsection{Volatility Metrics}

The following volatility metrics are calculated for target and acquiring firms around takeover announcements:

1. VWAP Volatility,

$$
\text { VWAP Volatility }=(\text { MAXPRICE }- \text { MINPRICE }) / \text { VWAP }
$$

2. TWMP Volatility,

$$
\text { TWMP Volatility }=(\text { MAXPRICE }- \text { MINPRICE }) / T W M P
$$

3. Standard deviation of trade to trade returns within an interval, where the returns are defined as the natural logarithm of the last trade price relative to the previous trade price.

In each case these calculations for the 63 2-hourly event periods are compared to the control period to isolate any abnormal behaviour.

\subsection{Liquidity Metrics}

To analyse the microstructure effects of informed trading occurring around takeover announcements the following metrics are examined (and compared to the control period values):

1. Time-Weighted Spread

$$
\text { TimeWeightedSpread }_{k}=\sum_{k=1}^{n}(\text { Ask }- \text { Bid })_{k} \text { Time }_{k} / \sum_{k=1}^{n} \text { Time }_{k}
$$

2. LIQUP

LIQUP represents the weighted number of shares that would need to be purchased so that the price of the stock would be 5 percent higher than the current midpoint price. It is defined as follows:

$$
\begin{gathered}
\text { LIQUP }=\sum_{k=1}^{n}\left(\text { Ask order price }{ }_{k}\right)\left(\text { Ask order quantity }{ }_{k}\right)(\text { Ask order weighting }) \\
\text { where; Ask order weighting }=\frac{\text { Price } 5 \% \text { above midpoint }- \text { Ask order price }{ }_{k}}{\text { Price } 5 \% \text { above midpoint }- \text { Midpoint price }} \\
\text { for all ask order prices where the order price is less than } 5 \% \text { above the midpoint. }
\end{gathered}
$$




\section{LIQDOWN}

LIQDOWN represents the weighted number of shares that would need to be sold so that the price of the stock would be 5 percent lower than the current midpoint price. It is defined as follows:

$$
\begin{gathered}
\text { LIQDOWN }=\sum_{k=1}^{n}\left(\text { Bid order price }{ }_{k}\right)\left(\text { Bid order quantity }{ }_{k}\right)(\text { Bid order weighting }) \\
\text { where; Bid order weighting }=\frac{\text { Bid order price } e_{k}-\text { Price } 5 \% \text { below midpoint }}{\text { Midpoint price }- \text { Price } 5 \% \text { below midpoint }} \\
\text { for all bid order prices where the order price is more than } 5 \% \text { below the midpoint. }
\end{gathered}
$$

\section{LIQUIDITY}

$$
\text { Liquidity }=\sqrt{L I Q U P \times L I Q D O W N}
$$

\subsection{Informed Trading Measure}

We develop a specific informed trading measure to further examine changes around takeover announcements. This measure calculates whether a trade resulted in a profit or a loss by comparing buyer and seller initiated trades to a reference price, as follows:

$$
\text { Informed Trade }=(B P+S P) /(B P+S P+B L+S L)
$$

Where:

$B P=$ Value of Buyer initiated trades that made a profit $=$ number of shares bought $*$ (reference price buying price),

$B L=$ Value of Buyer initiated trades that made a loss $=$ number of shares bought $*$ (reference price buying price),

$S P=$ Value of Seller initiated trades that made a profit $=$ number of shares sold $*$ (selling price - reference price),

$S L=$ Value of Seller initiated trades that made a loss $=$ number of shares sold $*$ (selling price - reference price).

A buyer initiated trade is identified as a profit trade if it is at a price that is below the reference price and a loss if its price is higher than the reference price. A seller initiated trade is identified as a profit trade if its price is higher than the reference price and a loss if it is lower. Evidence of investors making 
abnormal profits by taking short positions in acquiring firms and long positions in target firms prior to the announcement of a takeover is indicative of informed trading.

The reference price for target firms is the closing price on the $20^{\text {th }}$ trading day after the takeover announcement. Two prices are used for bidders. The first is the closing price on the $20^{\text {th }}$ trading day after an announcement (reference price 2) and the second is the closing price on the $250^{\text {th }}$ trading day after an announcement (reference price 3). We use this second reference price for acquirers to capture any longer run drift down in the bidder price (see for example Loughran and Vijh (1997)).

The bids in this study occur between 1997 and 2010. In order to control for changes in the market index occurring over the period between the date of the trade and the reference price date, the reference price is scaled by the following factor:

$$
\text { Index }_{t-1} / \text { Index }_{\text {ref }}
$$

Where:

$I_{(t-1)}=$ Index value at the close of trading the day before the interval

$I_{\text {ref }}=$ Index value at the close of trading on the reference price date.

\section{Empirical Results}

This section examines the abnormal behaviour of returns, volume, volatility, time-weighted spreads, liquidity and an informed trading metric for unanticipated ${ }^{6}$ takeover announcements made by the acquiring firms. The analysis will focus on the results obtained using a t-statistic test ${ }^{7}$ which tests for abnormal differences between the control and event period distributions generated using a bootstrap process $^{8}$.

\subsection{Abnormal Returns}

The results below focus on the VWAP return metric.

\section{Targets}

Figures 1 and 2present the abnormal and cumulative abnormal VWAP return behaviour for target firms over 63 intervals around the takeover announcement. For unanticipated takeover bids there is evidence of pre bid run-up in target firm shares. Further, highly significant abnormal returns are evident

\footnotetext{
${ }^{6} \mathrm{We}$ also calculated results for a combined sample of both unanticipated and anticipated takeover bids. Similar results are obtained for all metrics, however these results are of a lower magnitude as anticipated bids convolute the abnormal behaviour observed during the event period.

${ }^{7}$ As a robustness measure the results are also tested using a non-parametric Wilcoxon Rank Sum test. Similar results are obtained using this test.

${ }^{8}$ Alternative results obtained using a t-statistic test on the difference between control and event period metrics using the firm as its own control provide consistent conclusions.
} 
on the announcement. Abnormal returns remain mostly insignificant during the post announcement period, consistent with an efficient adjustment to the information in the bid.

Over the pre announcement period significant positive abnormal returns of between $0.3 \%$ and $0.65 \%$ are observed during $14^{9}$ separate intervals. Further, abnormal VWAP returns significantly increase to $1.07 \%$ during interval -6 . Figure 2 shows a steady increase in the cumulative abnormal VWAP returns ${ }^{10}$ during the entire pre announcement window. These findings support the notion that some investors have knowledge of the upcoming takeover announcement and are benefitting from the well documented pre bid run-up of the target firm's stock price. These patterns might of course be associated with the bidder building a toe-hold stake in the target.We test this possibility by investigating a sub-sample of 141 targets where the bidder does not acquire any toehold in the target (i.e., the "no toehold" targets). The results are similar; specifically for the full sample the CAR for the interval -30 to -3 is $4.39 \%$, while for the "no toehold" sample it is $3.35 \%$. Accordingly, while approximately one quarter of the pre-announcement abnormal returns can be associated with bidder toehold acquisition, there is still evidence of anticipation of takeover bids. We provide further analysis in Tables II and III below.

On the announcement date significant abnormal VWAP returns of $12.72 \%$ (13.10\% for the "no toehold" targets) are observed during the 10-12am opening interval as investors price the information in the takeover announcement. Abnormal returns (though of much smaller magnitude) continue until interval $+6(10-12 \mathrm{pm}$ interval $)$, which suggests that news of the takeover announcement, as well as the subsequent expectations of the bid being revised, becomes fully embedded into the target firms share price within two days of the announcement. During the remainder of the event periodabnormal VWAP returns fluctuate above and below $0 \%$.

Abnormal TWMP returns were also calculated for target firms. Similar results are found using this metric (however marginally lower) and hence they are not reported in detail.

\section{Acquirers}

Figure 3 and 4 (below) illustrate the behaviour of abnormal VWAP returns during the event period for acquiring firms. Before and after the announcement date most bidder abnormal returns fluctuate around $0 \%$; more importantly there is a significant decrease in returns in the two days prior to the announcement which suggests informed investors have prior knowledge of the bid. On the announcement date acquiring firms incur significant negative returns.

\footnotetext{
${ }^{9}$ Intraday patterns are observed as during 13 of these 14 intervals abnormal returns are observed in the $10-12 \mathrm{pm}$ or $2-4 \mathrm{pm}$ periods.

${ }^{10}$ The $\mathrm{t}$-statistic for cumulative abnormal VWAP returns is the summation of $\mathrm{t}$-statistics for each interval, divided by $\sqrt{N}$. This is based on the assumption of independence between each two hourly interval which is reasonable because in calendar time there is no considerable clustering of the deals included within the sample. A similar approach is used for cumulative TWMP returns and Informed Trading metric.
} 
Analysis of returns during the pre announcement period shows both significant positive and negative levels of abnormal return. There are eight (eight) returns that are significantly positive (negative) during the period -30;-1. During the two days prior to the announcement abnormal VWAP returns are significantly negative at a $10 \%$ significance level during intervals -5 to -3 . This result provides weak evidence to suggest the existence of informed trading as individuals who have inside knowledge of the takeover announcement, profit by selling the stock or taking a short position in the acquiring firm.

\section{Figure 1: Target Firm VWAP Return}

This figure shows Abnormal VWAP Return for target firms during the event period. The sample consists of 195 target firms which are the subject of an unanticipated takeover bid.

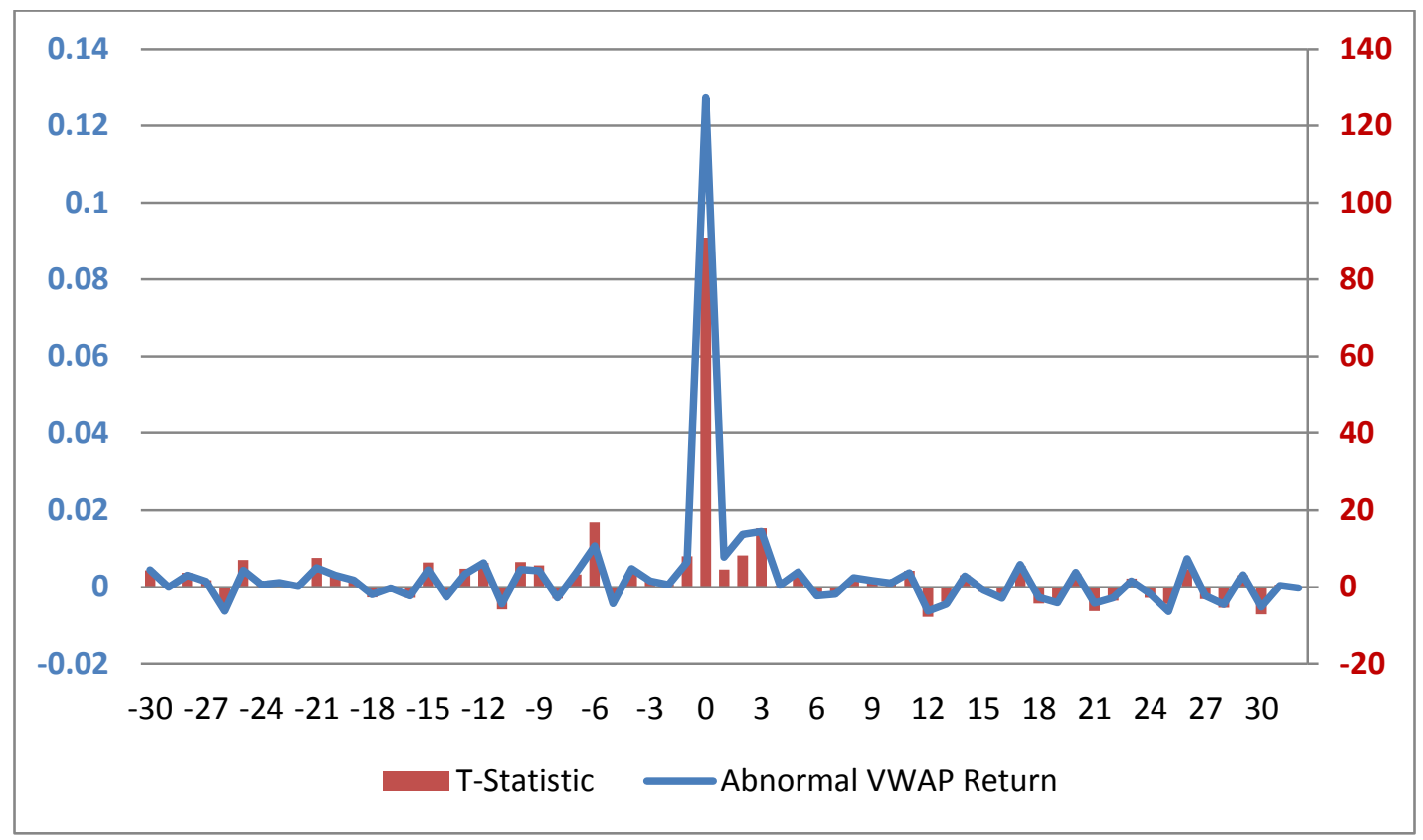


Figure 2: Target Firm Cumulative Abnormal VWAP Return

This figure shows Cumulative Abnormal VWAP Return for target firms during the event period. The sample consists of 195 target firms which are the subject of an unanticipated takeover bid.

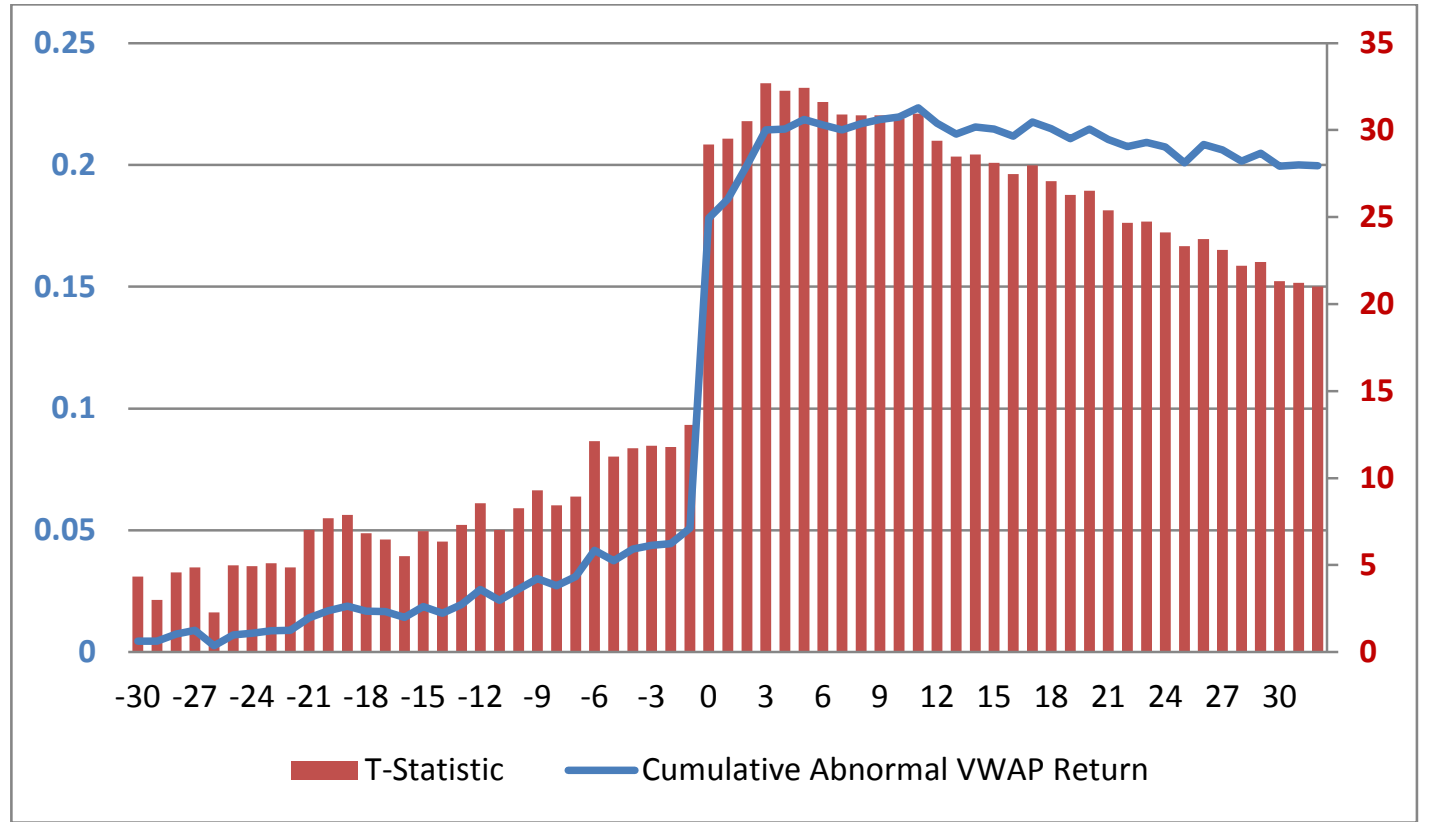

Figure 3: Acquiring Firm VWAP Return

This figure shows Abnormal VWAP Return for acquiring firms during the event period. The sample consists of 137 acquiring firms that make an unanticipated takeover bid.

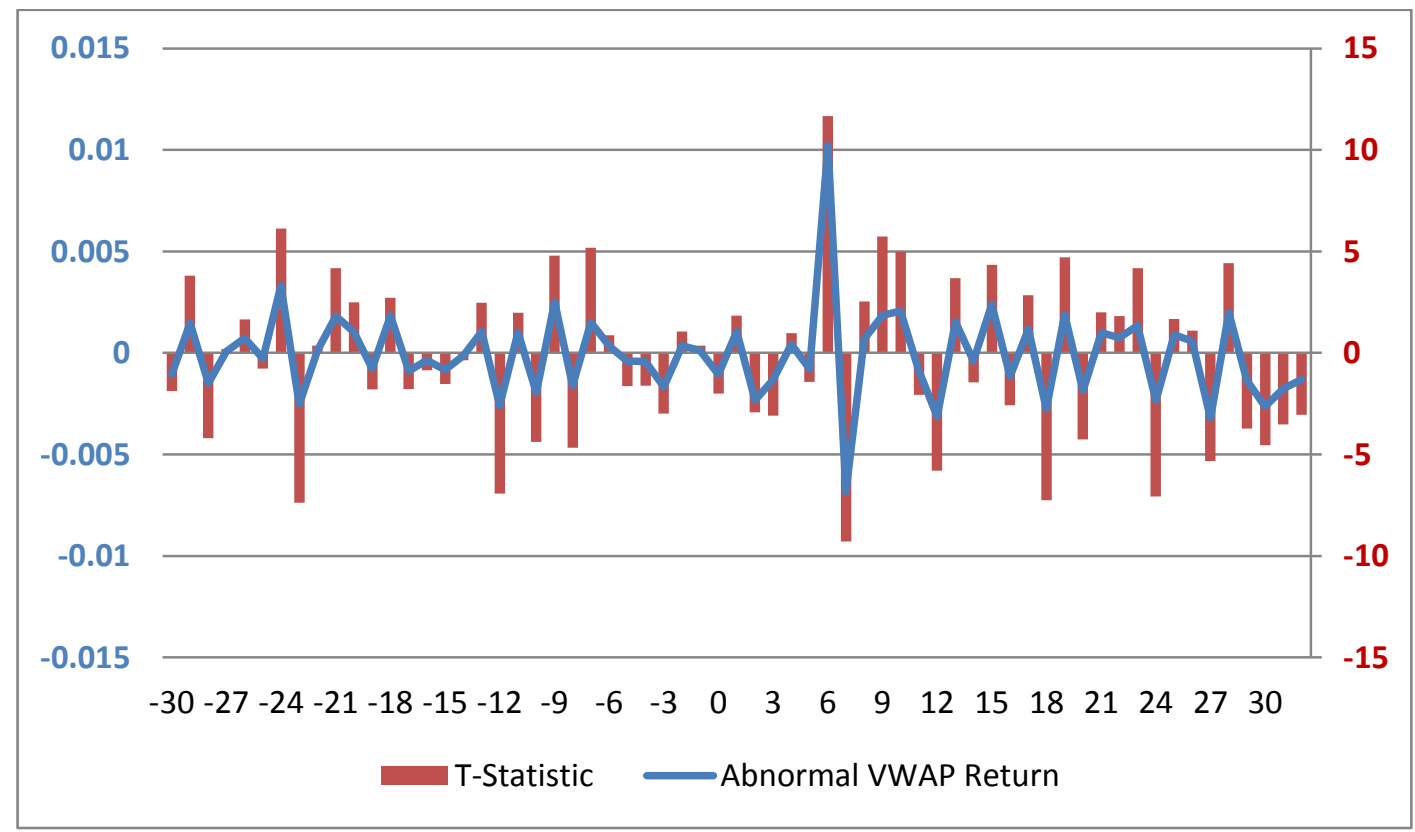


Figure 4: Acquiring Firm Cumulative Abnormal VWAP Return

This figure shows Cumulative Abnormal VWAP Return for acquiring firms during the event period. The sample consists of 137 acquiring firms that make an unanticipated takeover bid.

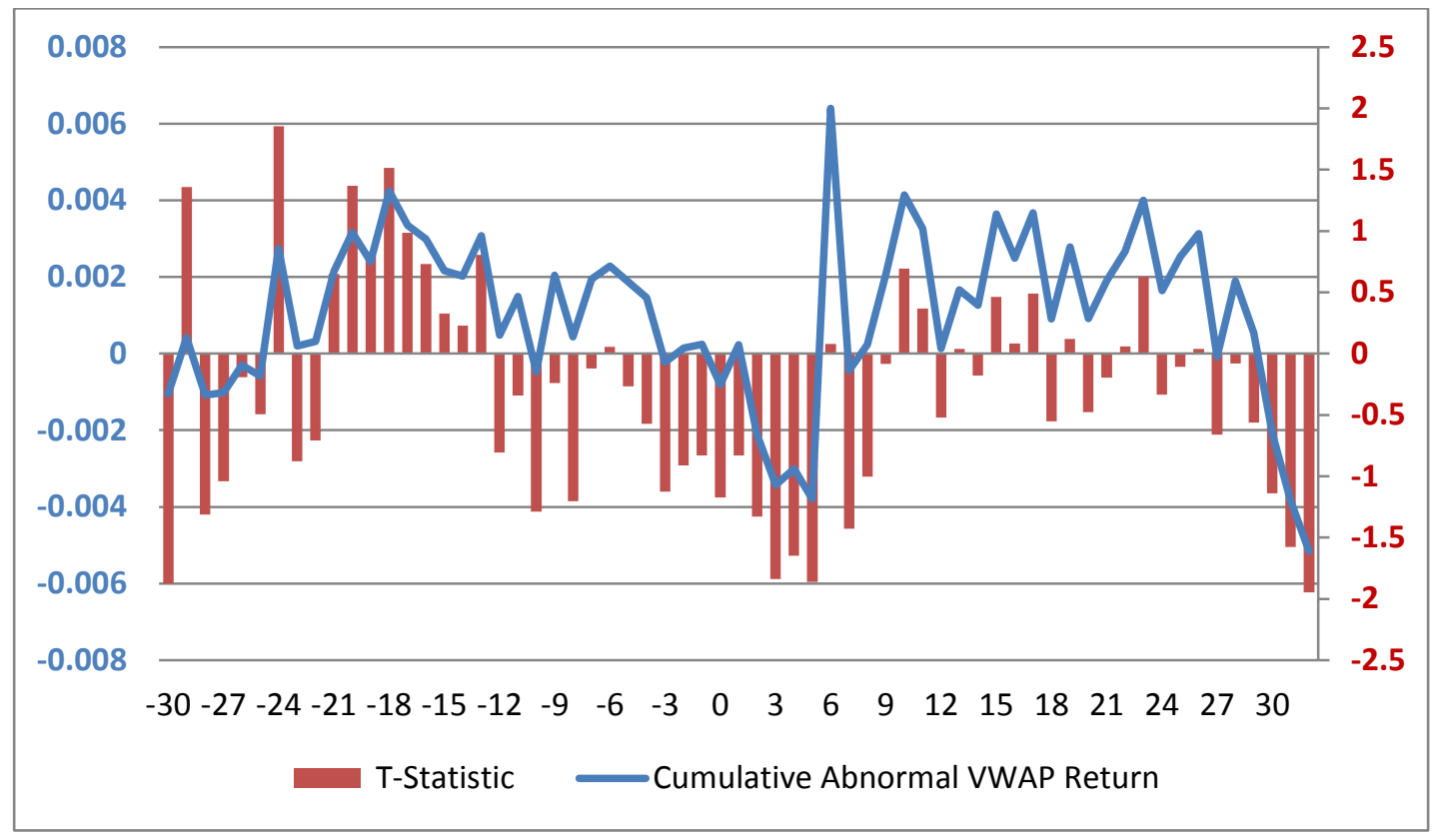

During intervals 0 and +2 (announcement date) and interval +3 (one day after the announcement) significant negative abnormal VWAP returns are observed. This result is consistent with the previous literature which explains that acquiring firms are penalised by the market on the announcement date as a result of offering a large premium for the target firm, or for undertaking bad acquisitions of target firms.

For the remainder of the post announcement period abnormal returns fluctuate around $0 \%$, in total 11 acquirer returns are significantly positive, while 13 are significantly negative. However, none of the CARs for acquirers in the entire investigation window show strong statistical deviation from zero ${ }^{11}$. An unexpected finding (which is probably due to chance) is observed during intervals $+6(+7)$ where acquiring firms earn an abnormal return of approximately $1 \%(-0.6 \%)$.

Again, the TWMP returns for these intervals are consistent in sign, but of much lower magnitude, and hence are not reported in detail ${ }^{12}$.

\subsection{Abnormal Volume}

For both target and acquiring firms four different volume metrics (total volume, total value of trading, the number of trades and the average trade size)are examined during the event period. The behaviour of

\footnotetext{
${ }^{11}$ The maximum t-stat is 1.8521 in interval -24 , while the minimum is -1.9485 in interval +32 .

${ }^{12}$ They are, of course, available on request to the corresponding author.
} 
these metrics is similar, and as a result the analysis in this section will focus on abnormal total volume results.

\section{Targets}

During the pre announcement period there is evidence of abnormal increases in volume, especially closer to the announcement date. On the announcement date there is significant increase in volume. The abnormal behaviour in volume shows a jagged downtrend (with clear evidence of intraday patterns) during the post announcement period.

Figure 5 reveals significant abnormal increases in trade volume for 18 of the 30 intervals in the pre announcement period for targets. More specifically this increase in volume is observed during nine of the ten intervals directly preceding the announcement date. Further we observe intraday patterns in volume (increased volume during the 10-12pm and $2-4 \mathrm{pm}$ intervals) during the four days prior to the announcement. In addition to the results observed for returns, these findings provide evidence to support the notion of some information leakage leading to informed trading taking place prior the takeover announcement. For the sample of 141 "no toehold" targets there are significant increases in trade volume in 19 of the 30 intervals; again nine of the last ten intervals prior to announcement have significant increases in volume. Thus the observed increases in pre-bid volume are not caused by toehold acquisition by the bidder, and are more likely explained by information leakage to informed traders. On the announcement date abnormal trade dramatically increases. Volume increases during all three two hourly periods as investors and the bidding firm stands ready to purchase target firm shares at the bid price. This volume surge is partly due to hedge fund activity as they build a long position in the target. The most common hedge fund strategy is to buy the shares of the target in expectation that the bid price will be revised upward. 
Figure 5: Target Firm Total Volume

This figure shows Abnormal Total Volume for target firms during the event period. The sample consists of 195 target firms which are the subject of an unanticipated takeover bid.

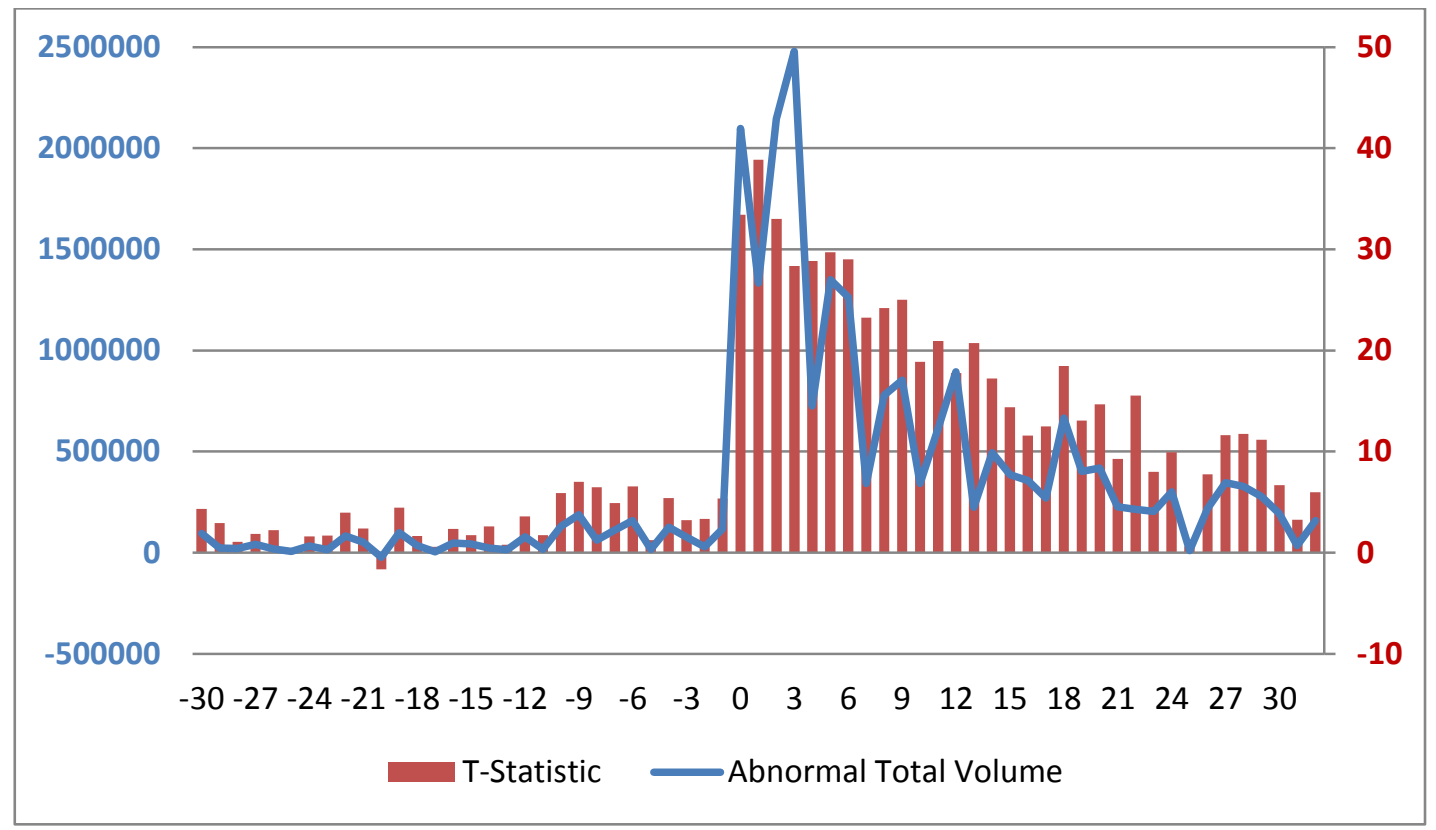

Figure 6: Target Firm Average Trade Size

This figure shows Abnormal Average Trade Size for target firms during the event period. The sample consists of 195 target firms which are the subject of an unanticipated takeover bid.

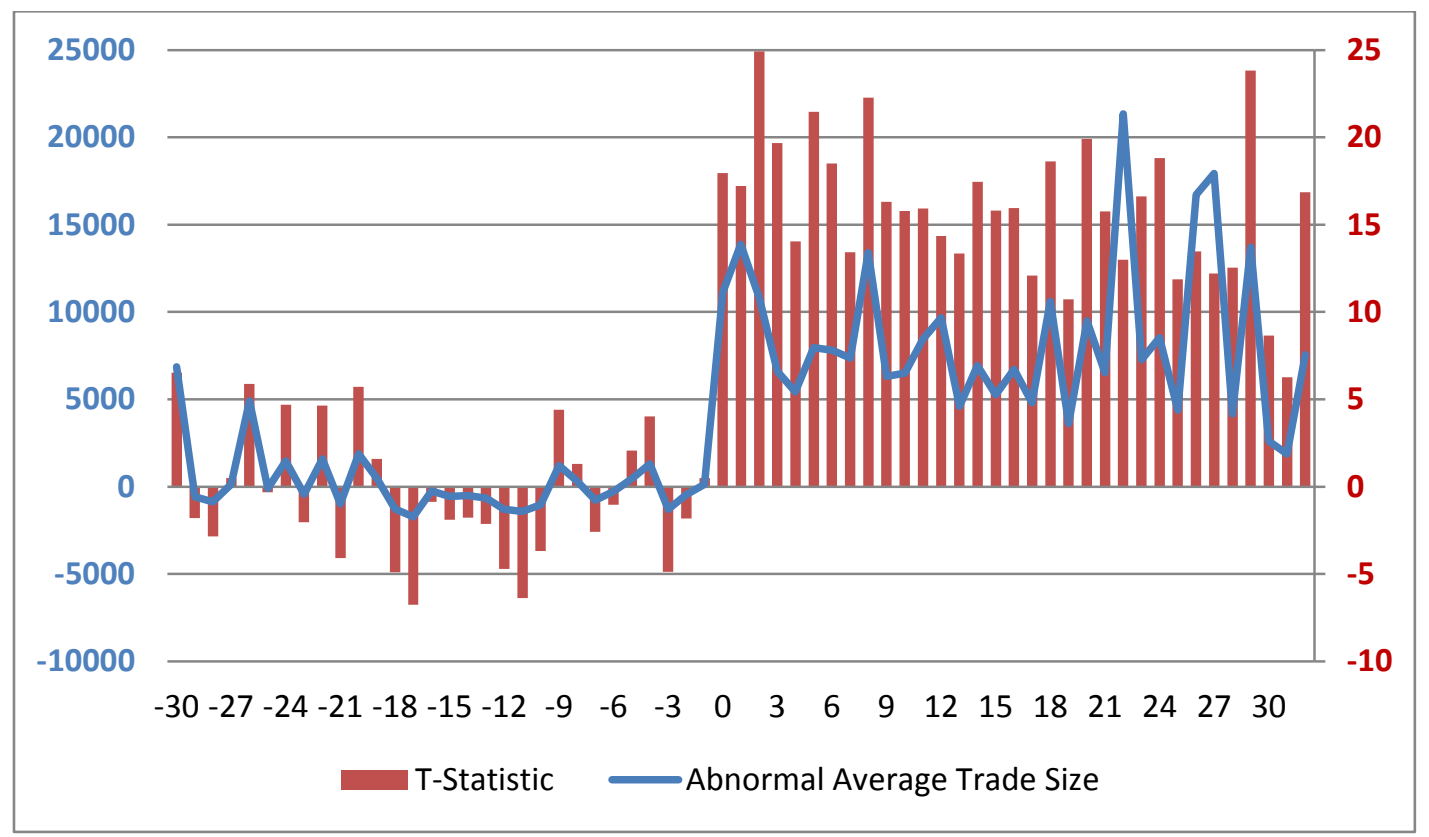


During the post announcement period abnormal volume is observed in 31 of the 32 intervals for both target samples, however the level of abnormal volume diminishes toward the end of this period. Ceteris paribus the effect of the announcement has a significant impact upon volume for up to 10 trading days after the announcement.

Analysis of total value, total number of trades and average trade size show similar results to those observed for total volume. One key difference in the results obtained for these metrics is that whilst total volume, value and number of trades are significantly positive in at least six of the ten intervals prior to the announcement date, average trade size (Figure 6) is significantly negative or insignificant in seven of these ten intervals ${ }^{13}$. Such behaviour indicates that smaller investors are selling. Another key difference is that average trade size remains significantly positive (and at a reasonably constant level) for the remainder of the post announcement period, whilst the other volume metrics trend downwards as news of the announcement becomes embedded in the targets share price.

\section{Acquirers}

The acquired volume results show that between intervals -30 to -19 significant positive levels of total volume (Figure 7), value and number of trades (not reported). In contrast, average trade size (Figure 8) is significantly negative during most of these same intervals. During this period (which corresponds to two weeks before the bid), the results suggest that informed traders increase the volume, value and number of trades, whilst reducing the average size of their trades, perhaps in an attempt to hide their trades from the market. As the pre announcement period draws to a close (-18 to -1), volume, value and number of trades are insignificant, which does not suggest informed trading around takeover announcements. In this period average trade size (Figure 8) is significantly positive on six occasions, though it is significantly negative in ten intervals. It needs to be noted, of course, that the opportunity to benefit from advanced knowledge of a takeover is more likely to be evident in the trade volume of the target (and perhaps in call option trading in targets).

During the morning session of the announcement date (10-12pm) only abnormal total volume and value significantly increase. However, during the $12-2 \mathrm{pm}$ and $2-4 \mathrm{pm}$ intervals all four metrics display abnormal behaviour, as investors trade on the news. By interval +18 the effect of the takeover announcement upon total volume, value and number of trades becomes insignificant. In contrast, abnormal average trade size fluctuates between -1000 and 3000 units during the post announcement period, with most intervals displaying an increase in transaction size.

\footnotetext{
${ }^{13}$ For the 141 sample eight of these ten intervals are significantly negative or insignificantly different to zero.
} 
Figure 7: Acquiring Firm Total Volume

This figure shows Abnormal Total Volume for acquiring firms during the event period. The sample consists of 137acquiring firms that make an unanticipated takeover bid.

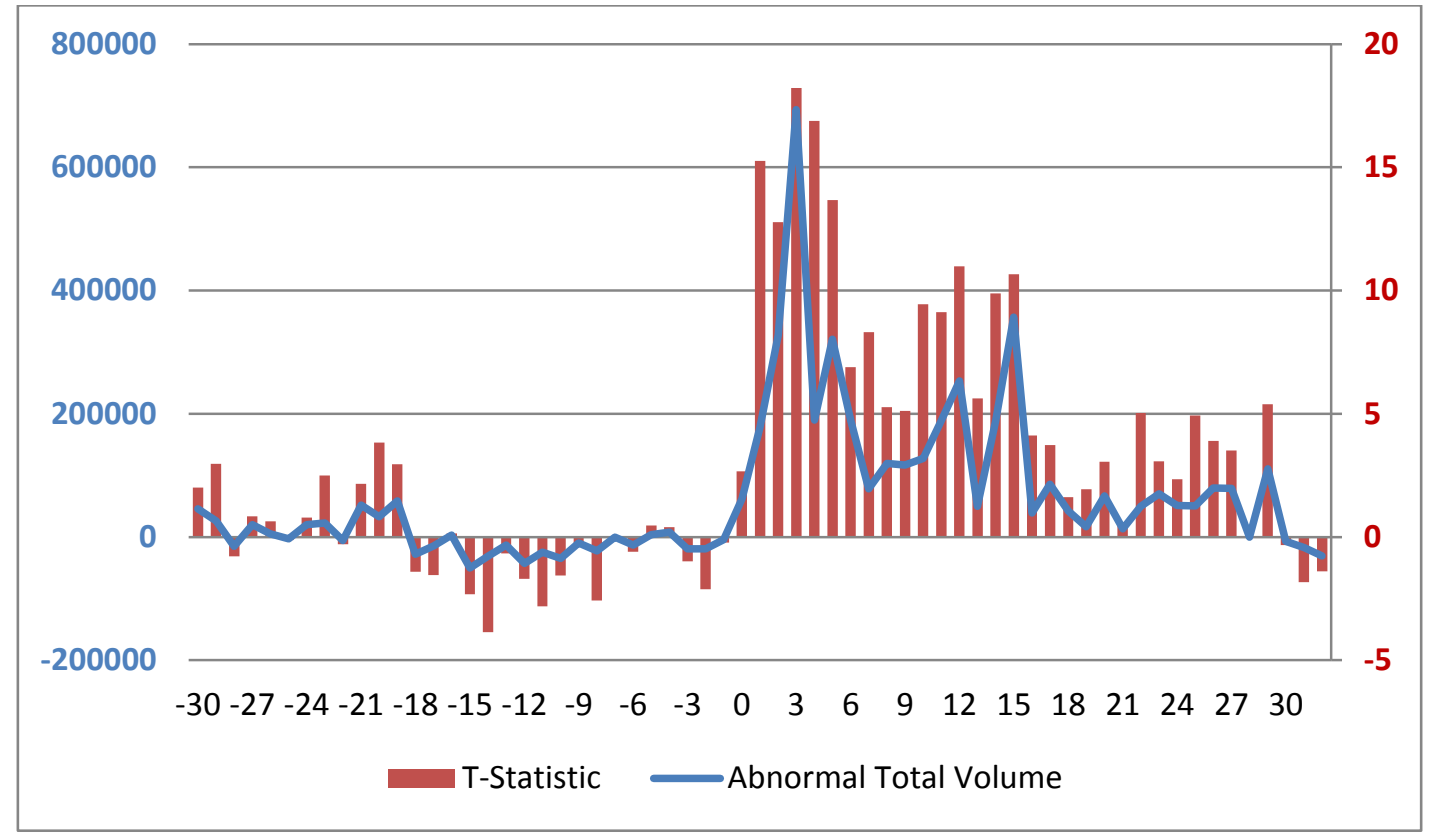

Figure 8: Acquiring Firm Average Trade Size

This figure shows Abnormal Average Trade Size for acquiring firms during the event period. The sample consists of 137 acquiring firms that make an unanticipated takeover bid.

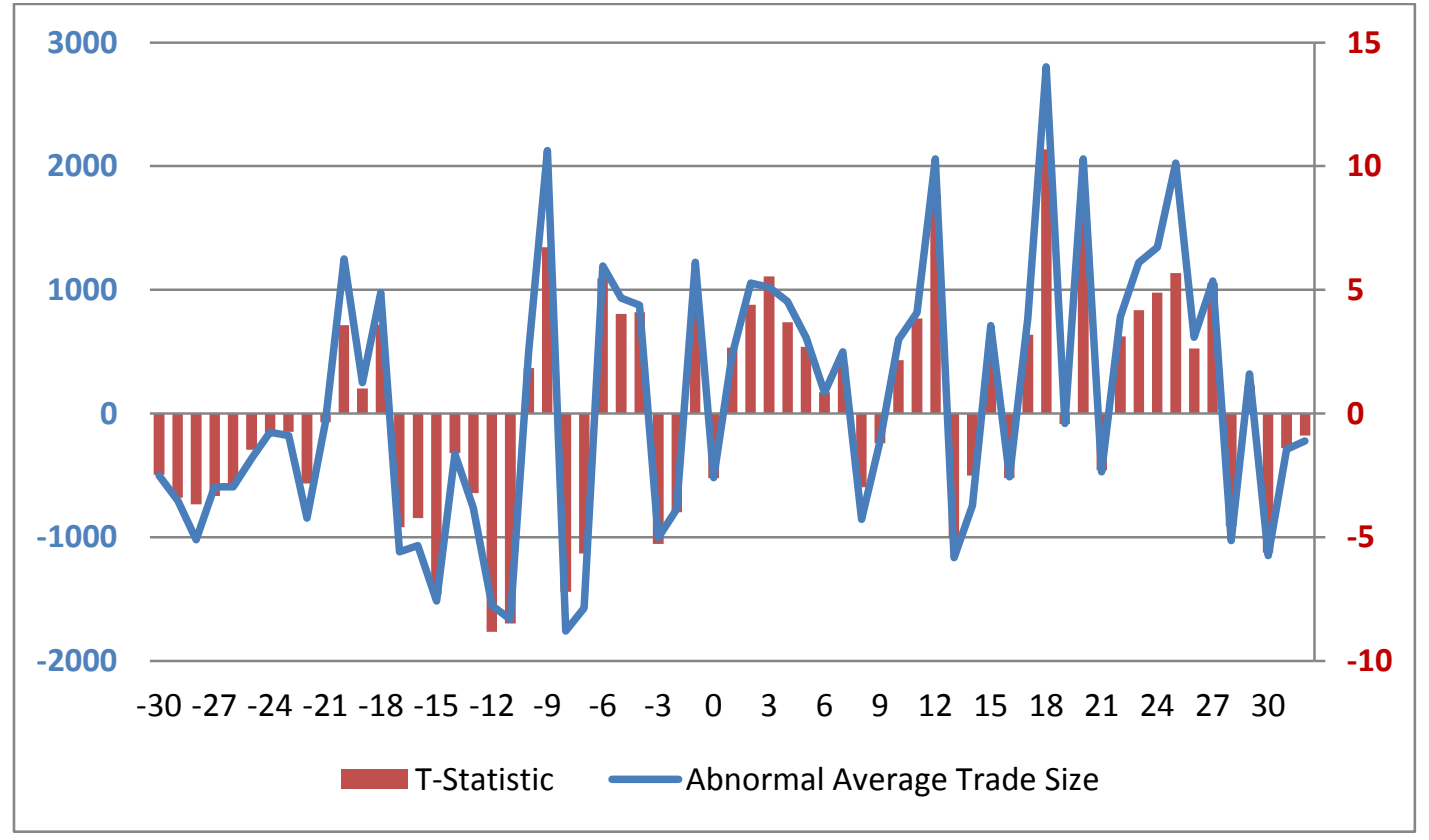




\subsection{Abnormal Volatility}

The behaviour for target and acquiring firm abnormal volatility is discussed in this section. Again, similar results were obtained using all three volatility metrics (i.e., VWAP volatility, TWMP volatility and the standard deviation of trade to trade returns), and hence the analysis below focuses on VWAP volatility. The results discussed above show that there are a number of intervals in which returns and volumes are abnormally elevated for target firms. It can be expected that in these periods there will also be abnormal changes in volatility. In confirmation, the results find significant positive levels of volatility during the pre announcement period. A large spike in volatility is observed on the announcement date, before significant negative levels of volatility are observed in the post announcement period.

\section{Targets}

During the pre announcement period abnormal VWAP volatility (Figure 9) fluctuates between $-0.5 \%$ and $0.65 \%$, with 16 intervals of significant positive volatility interspersed with four intervals of significant negative volatility. Analysis of returns, volume and volatility together reveals that positive increases in all of these metrics is observed during 11 intervals, however this relationship is only significant during intervals $-21,-12,-10,-4$ and -2 .

On the announcement date, consistent with significant abnormal increases in returns and volume, VWAP volatility significantly increases. During the morning period of the announcement date VWAP Volatility peaks at $2.17 \%$. This abnormal surge in volatility lasts until the12-2pm interval (Interval +4$)$ on the day following the announcement, after which VWAP volatility is significantly negative until interval +10 , consistent with resolution of uncertainty regarding the bid's prospects.

\section{Acquirers}

For acquiring firms (Figure 10) VWAP volatility is generally significantly negative during the pre announcement period, significantly positive on the announcement date and it then fluctuates above and below zero during the post announcement period.

During the pre announcement period the significantly ${ }^{14}$ negative levels of volatility is evident in all three metrics. This behaviour can be attributed to the significant negative returns and volume observed in acquiring firms prior to the takeover announcement. During the 10-12pm and 12-2pm sessions on the announcement date volatility significantly increases as investor's react to the uncertainties implicit in the bid. Consistent results are found in the behavior of the other two volatility metrics on the announcement date.

\footnotetext{
${ }^{14}$ The pronounced downward spikes in abnormal volatility observed during intervals -28 and -13 for both VWAP volatility metrics are driven by outliers. These spikes are also present in the TWAP volatility results (not reported).
} 
Figure 9: Target Firm VWAP Volatility

This figure shows Abnormal VWAP Volatility for target firms during the event period. The sample consists of 195 target firms which are the subject of an unanticipated takeover bid.

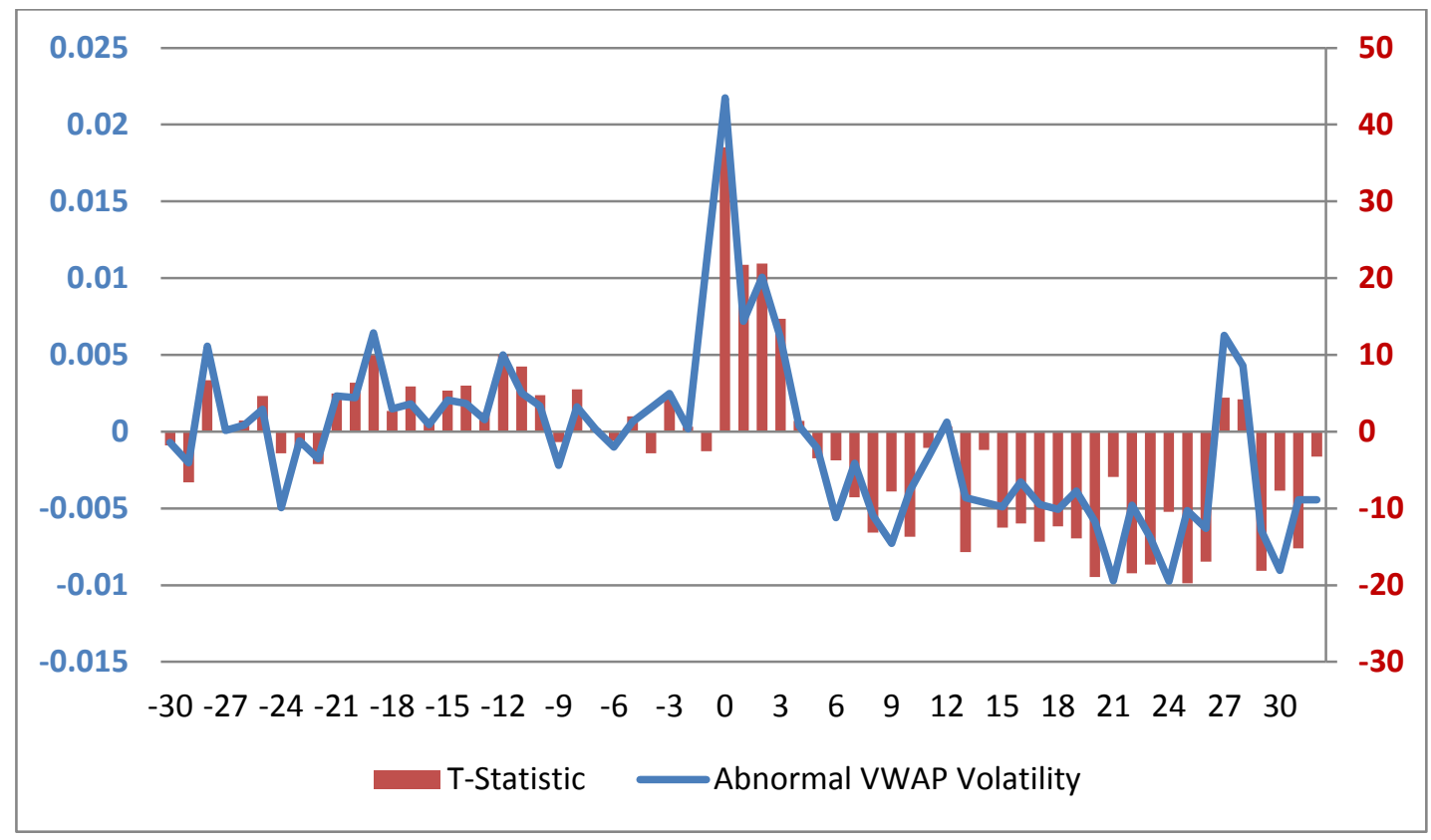

Figure 10: Acquiring Firm VWAP Volatility

This figure shows Abnormal VWAP Volatility for acquiring firms during the event period. The sample consists of 137 acquiring firms that make an unanticipated takeover bid.

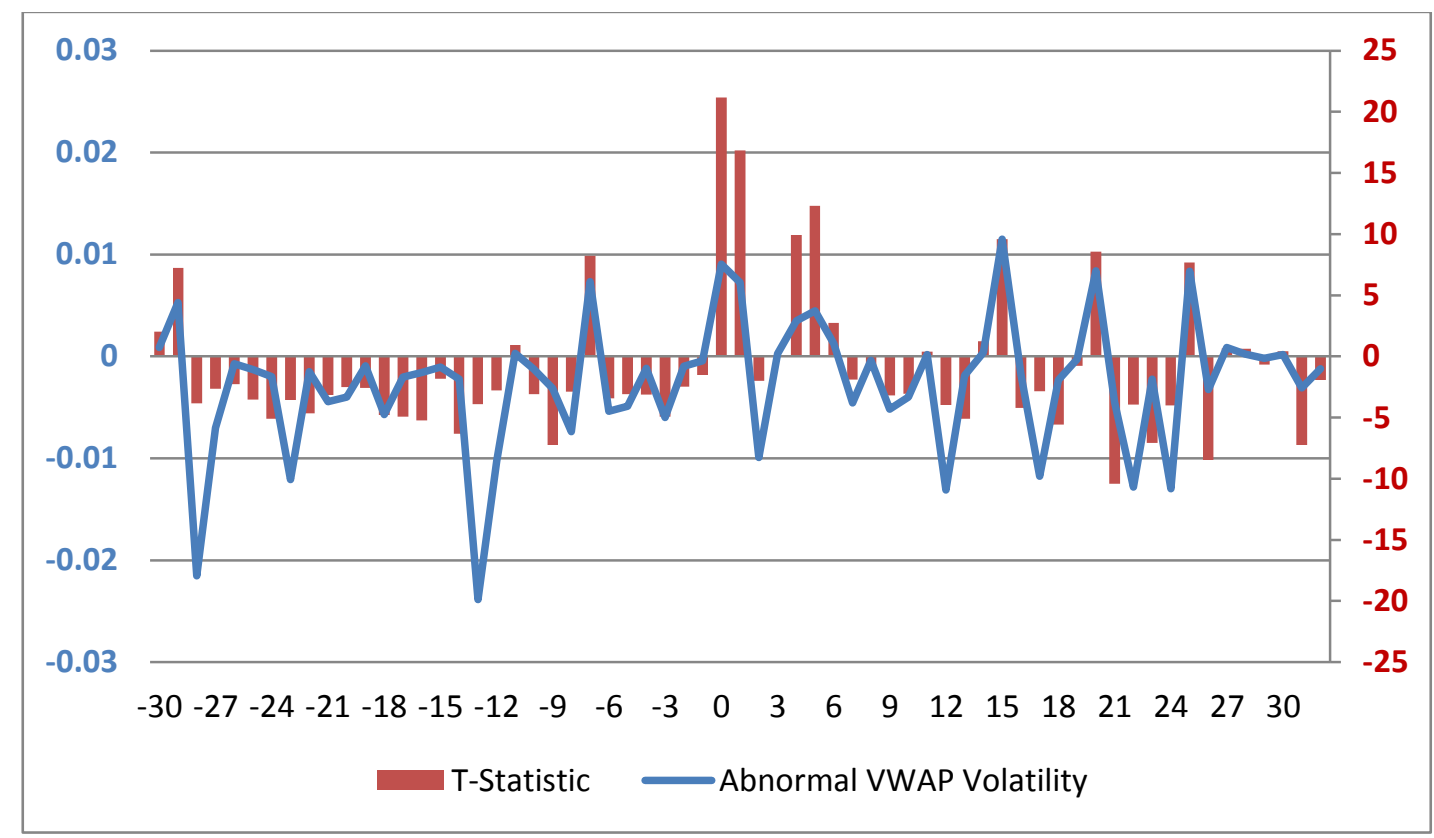


However the magnitude varies between the three volatility metrics. VWAP and TWMP volatility show that volatility increases to approximately $0.9 \%$, whereas the standard deviation reveals that volatility increases to $2.5 \%$. Further, consistent with the trends in returns and volume, volatility fluctuates between $-1 \%$ and $1 \%$ during the post announcement period.

\subsection{Abnormal Time-Weighted Spread}

In the following sections several microstructure metrics that proxy for the level of information asymmetry are examined. A widening of the bid ask spread prior to a takeover announcement is indicative of dealers protecting themselves from trading with informed traders, or increased levels of asymmetric information among market participants. A majority of prior studies which examine bid ask spreads and adverse selection costs have been conducted in the U.S. within specialist markets, in which prices are determined from quotations posted by specialist dealers. This study focuses on firms listed on the ASX, which is an order driven market in which spreads and prices are determined by the flow of buy and sell orders. Glosten (1994) argues that the bid ask spread is positive due to the existence of adverse selection costs within order driven markets. Further, Brockman and Chung (1999) posits that the bid ask spread "represents the expected compensation for the costs of supplying immediacy." These studies argue that spreads in order driven markets are similar to spreads set in quote driven markets.

\section{Targets}

Figure 11 displays the behaviour of the abnormal bid ask spread for target firms around takeover announcements in Australia. The results show that spreads widen up to four days before the announcement, reflecting increased dispersion in investor information. Similarly, abnormally elevated spreads are observed on the announcement date. During the post announcement period both positive and negative abnormal time-weighted spreads are observed for the 195 targets, though for the 141 "no toehold" sample, the spreads are consistently negative at approximately -0.01 .

The abnormal time-weighted spread is significantly negative between intervals -21 to -16 in the pre announcement period reaching a low of -0.016 . Relative to the control period this behaviour in the spread suggests that there is no additional information asymmetry between investors. However, during intervals $12,-11,-8$ and -7 the observed abnormal spread is significantly positive, increasing to a maximum value of 0.013. An increased spread during these intervals could be explained from an increase in adverse selection costs due to increased information asymmetry between investors. ${ }^{15}$ However, during the six

\footnotetext{
15 The results in this paper are restricted to the behaviour of the total bid ask spread. An area of further research would aim to decompose the spread into specific components in order to increase the validity of informed trading inferences. We would expect that in the period directly before the announcement date the spread would widen if informed trading was prevalent within target firm shares.
} 


\section{Figure 11: Target Firm Absolute Spread}

This figure shows Abnormal Absolute Spread (in cents) for target firms during the event period. The sample consists of 195 target firms which are the subject of an unanticipated takeover bid.

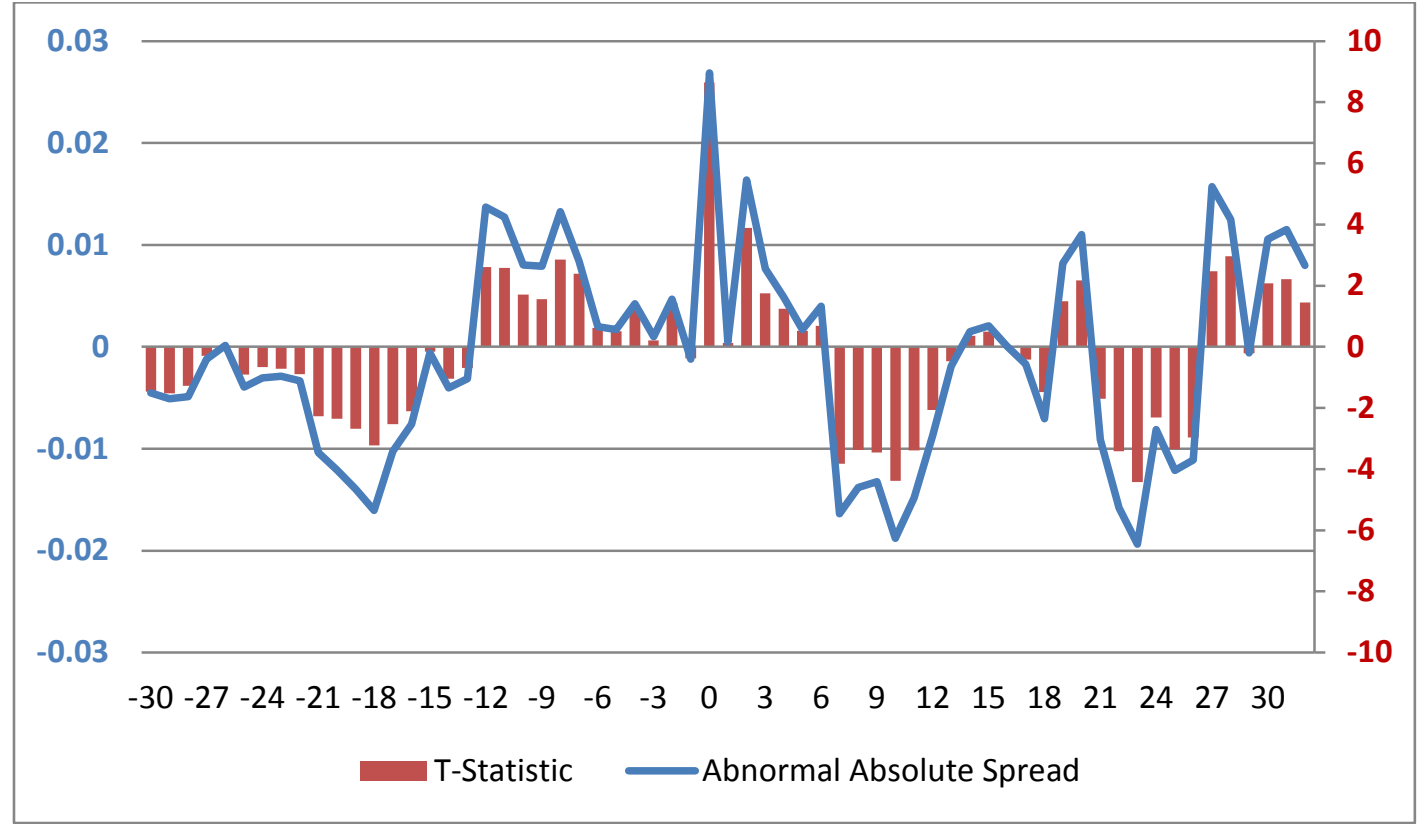

Figure 12: Acquiring Firm Absolute Spread

This figure shows Abnormal Absolute Spread (in cents) for acquiring firms during the event period. The sample consists of 137 acquiring firms that make an unanticipated takeover bid.

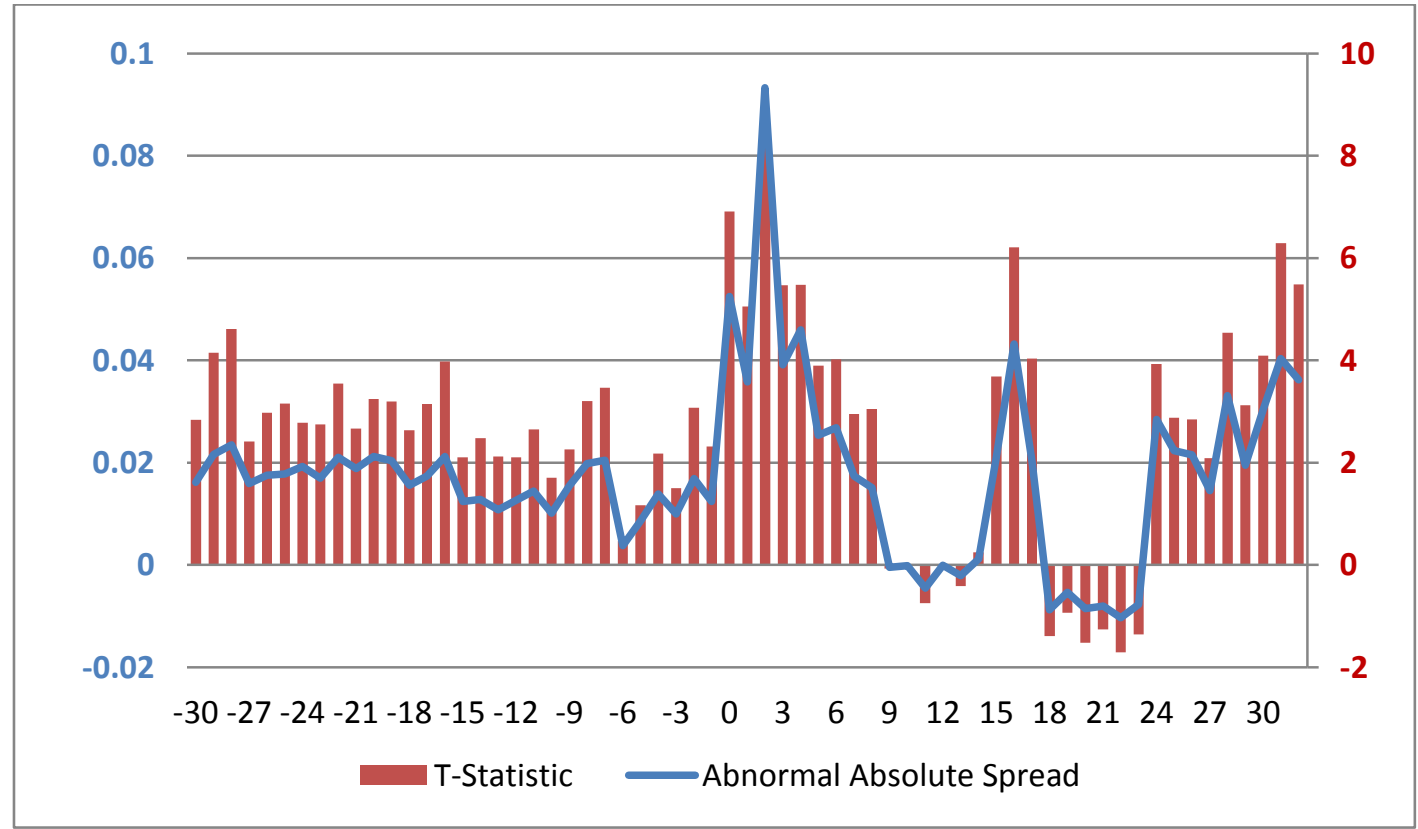


intervals prior to the announcement date the spread remains insignificantly different from its expected value.

On the announcement date the abnormal time-weighted spread peaks at 0.026 during the $10-12 \mathrm{pm}$ morning session. This increase in the spread is most likely attributed to divergence in investor opinion. On the day following the announcement the abnormal time-weighted spread becomes insignificant. Further, between intervals +7 to +12 and +20 to +26 the abnormal time-weighted spread is significantly negative. Such behaviour can be expected after a period of uncertainty (takeover announcement) and also as a result of abnormal levels of volume and liquidity during these intervals ${ }^{16}$. During these intervals the market is deeper as a result of the acquiring firm standing in the market ready to acquire the target firm's shares.

\section{Acquirers}

Figure 12 depicts the abnormal behaviour of the time-weighted spread during the event period for acquiring firms. Significant abnormal behaviour of time-weighted spreads is evident throughout the pre announcement period, before spiking on the announcement date. In addition, significant spikes in timeweighted spread are observed in the post announcement period.

Throughout the pre announcement period the bid ask spread remains significantly elevated and ranges between 0.01 and 0.02 . During intervals -7 and -6 the spread is insignificant but during intervals -5 to -1 an upward trend in spreads is evident. Thus, these results provide evidence which suggests the existence of asymmetric information prior to takeover announcements.

On the announcement date the time-weighted spread increases to approximately 0.09. Again, this behaviour could be the result of an increase in the diversity of investor beliefs. The announcement effect on the bid ask spread lasts until interval +8 , two days after the announcement date. During the post announcement period significant time-weighted spreads are observed during intervals +15 to +17 and intervals +24 to +32 . This behaviour can be attributed to information asymmetry between investors as to whether the takeover bid from the acquiring firm will succeed, whether the bid will be revised and to whether a competing bid will be made.

\subsection{Abnormal Liquidity}

The U.S. literature has found that dealers manage the risk of trading with an informed trader by widening the spread and decreasing quoted depth. This ultimately minimises the probability of trading with an informed trader and incurring trading losses. Three SMARTS proxies for liquidity are reported, namely Liqup, Liqdown and Liquidity. Liqup provides a summary statistic of the sell side of the order book and measures the number of shares that would have to be traded to cause the ask price to move up

\footnotetext{
${ }^{16}$ See Volume (above) and Liquidity (below) metrics during intervals +7 to +12 and +20 to +26 .
} 
by $5 \%$. Liqdown provides a summary statistic of the buy side of the order book and calculates the number of shares that would have to betraded to cause the bid price to move down by $5 \%$. Liquidity is a measure of the overall depth of the bid and ask side of the order book. ${ }^{17}$

\section{Targets}

The results show that Liqup (Figure 13) and Liqdown (Figure 14) and Liquidity (Figure 15) are generally significantly elevated during the pre announcement period. The release of the takeover announcement to the market results in a dramatic increase in all three liquidity metrics, and this elevation is maintained throughout the post-announcement window, though the metrics trend downwards as acceptances of the offer result in decreased liquidity. As expected, the buy-side of the order book in the post announcement period has much greater depth (it averages approximately 25 million shares soon after the announcement and declines to around 10 million shares) than the sell-side (with an average of approximately 1.2 million shares).

\section{Figure 13: Target Firm Liqup}

This figure shows Abnormal Liqup for target firms during the event period. The sample consists of 195 target firms which are the subject of an unanticipated takeover bid.

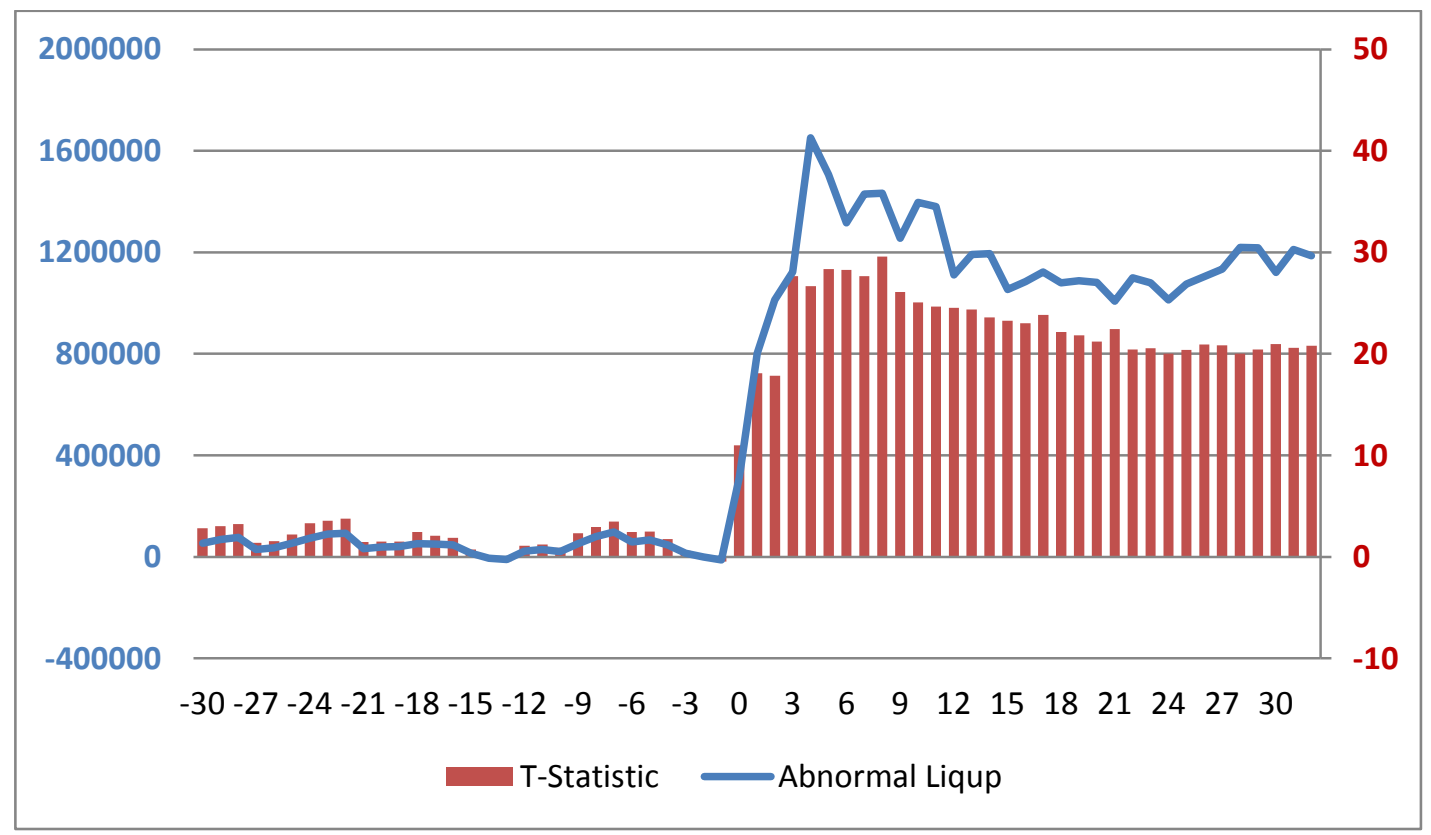

\footnotetext{
${ }^{17}$ The three liquidity metrics for the 141 targets and 195 targets display very similar patterns in the period prior to the announcement, and hence toehold acquisition by the bidder, when it occurs (i.e., in 54 targets), is conducted with finesse.
} 
Figure 14: Target Firm Liqdown

This figure shows Abnormal Liqdown for target firms during the event period. The sample consists of 195 target firms which are the subject of an unanticipated takeover bid.

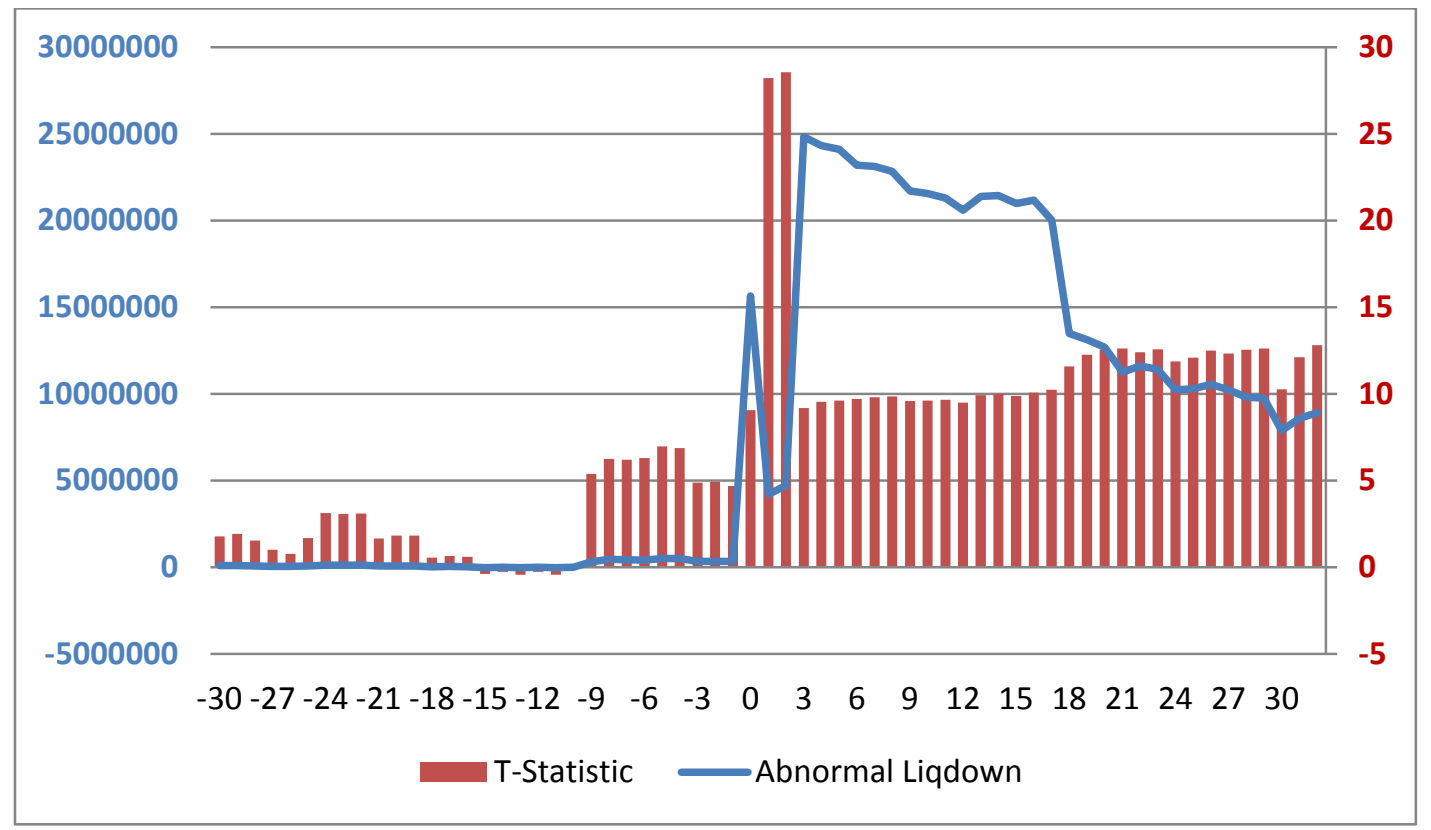

Figure 15: Target Firm Liquidity

This figure shows Abnormal Liquidity for target firms during the event period. The sample consists of 195 target firms which are the subject of an unanticipated takeover bid.

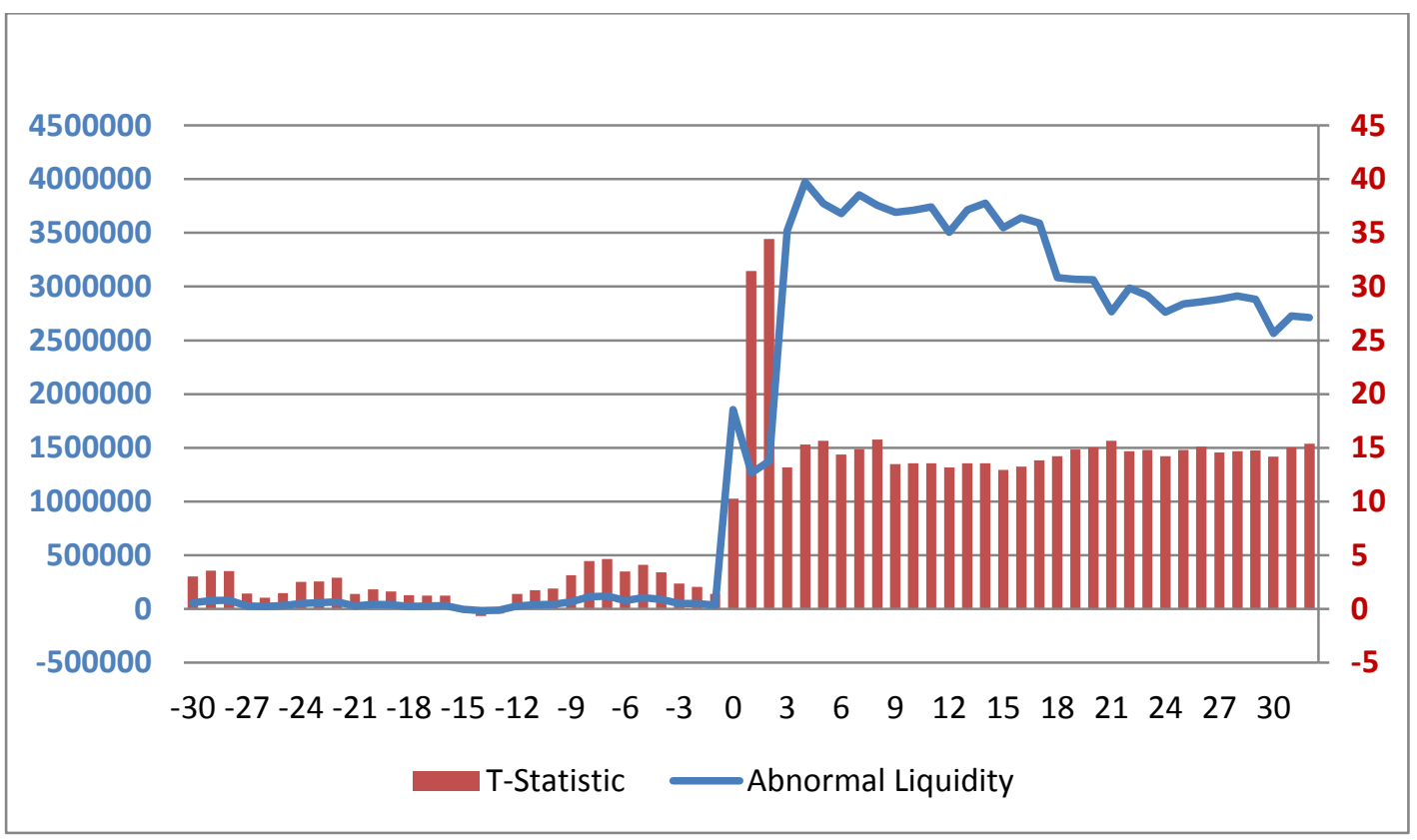


Analysis of Liqup reveals significant increased behaviour for 14 of 30 intervals during the pre announcement period. For example, this finding is observed between intervals -9 to -5 which provides evidence against the existence of informed trading, as informed individuals would not sell target firm shares prior to the takeover announcement and miss the opportunity to profit from the pre bid run-up and significant announcement date returns.

Analysis of Liqdown during the pre announcement period shows a significant increase in the depth of buy orders of target firms, beginning in the morning session three days prior to the takeover announcement. Two explanations are possible. Firstly, acquiring firms might have orders to buy, as prior to the takeover announcement the acquiring can be expected to attain a toehold in the target firm. In addition, such abnormal behaviour can provide evidence to suggest the presence of (other) informed traders purchasing target firms prior to the takeover announcement.

A comparison of Liqup and Liqdown for targets shows dramatic changes in the order book close to the takeover announcement with much greater change in depth on the bid side. For example in the three days prior to the takeover announcement the average Liqdown metric is approximately 500,000 shares, while for Liqup it is less than 100,000 shares. The value of Liqdown in the post-announcement period always exceeds 10 million shares, while for Liqup it is approximately 1.2 million.

The combination of the Liqup and Liqdown metric results in the Liquidity plot metric displayed above (Figure 15). The Liquidity metric is significant during intervals -25 to -22 and particularly in intervals -9 to -5 ; the latter being due to dramatic increases in Liqdown during the three days prior to the announcement date and relatively minor increases in Liqup.

During all three intervals on the announcement date Liqup, Liqdown and Liquidity significantly increase. The release of new information into the market results in the order book being dominated by the buy side, as investors look to profit from the positive effect of the takeover upon the target firms share price. During the morning session (10-12pm) the number of buyer initiated purchases is approximately 50 times the number of seller initiated tradesin target firm's shares.

After the announcement date both Liqup and Liqdown exhibit a downtrend throughout the post announcement period. Liqup peaks at 1.65 million shares during interval +4 before leveling out to approximately 1.2 million shares. On the other hand, Liqdown reaches a maximum of 24.8 million shares during interval +3 prior to settling at around 10 million shares. The significance of Liqdown just after announcement is likely to be caused by the acquiring firm standing in the market as a buyer. A similar trend is also evident in the Liquidity plot (Figure 15).

\section{Acquirers}

Figures 16, 17 and 18 illustrate the abnormal behaviour of Liqup, Liqdown and Liquidity respectively for acquiring firms during takeover announcements. In the pre announcement period we observe 
significant spikes in Liqup, whilst Liqdown and Liquidity remain insignificant. On the announcement date Liqup is insignificantly different to its behaviour in the control period, Liqdown significantly increases toward the end of the trading day, whilst Liquidity remains insignificant. Following this, significant spikes in all three metrics are observed in the post announcement period. It is worth keeping a comparison to the targets in mind when interpreting acquiring firm liquidity. Recall that the targets are about one-half the size of the bidders. Yet abnormal levels of liquidity for the targets in the postannouncement period of 3 million shares are much greater than the liquidity increase for bidders of approximately 150,000 shares.

During the pre announcement period significant increases in abnormal Liqup are seen between intervals -24 to -13 and interval -2 . This behaviour could be explained by the presence of informed traders who are prepared to sell or short acquiring firm shares, to potentially profit from the (typically observed) underperformance of the acquiring firm's stock price around takeover bids. As one would expect, Liqdown remains insignificant for 27 of 30 intervals during the pre announcement period. This result provides some support to the existence of informed trading, as informed investors would withdraw from the bid side of the order book so as to not purchase the acquiring firm shares prior to a takeover announcement.

\section{Figure 16: Acquiring Firm Liqup}

This figure shows Abnormal Liquidity for acquiring firms during the event period. The sample consists of 137 acquiring firms that makean unanticipated takeover bid.

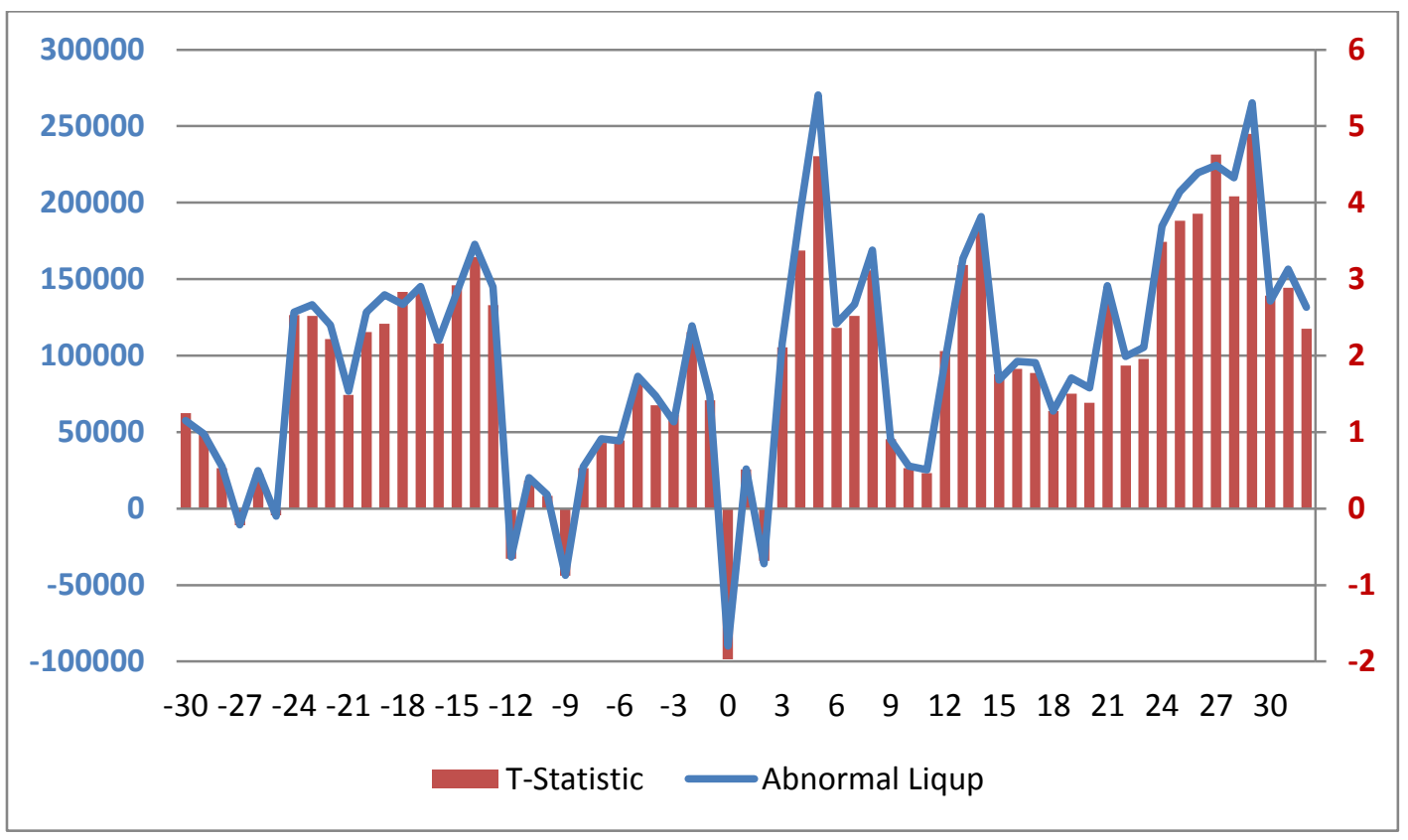


Figure 17: Acquiring Firm Liqdown

This figure shows Abnormal Liqdown for acquiring firms during the event period. The sample consists of 137 acquiring firms that make an unanticipated takeover bid.

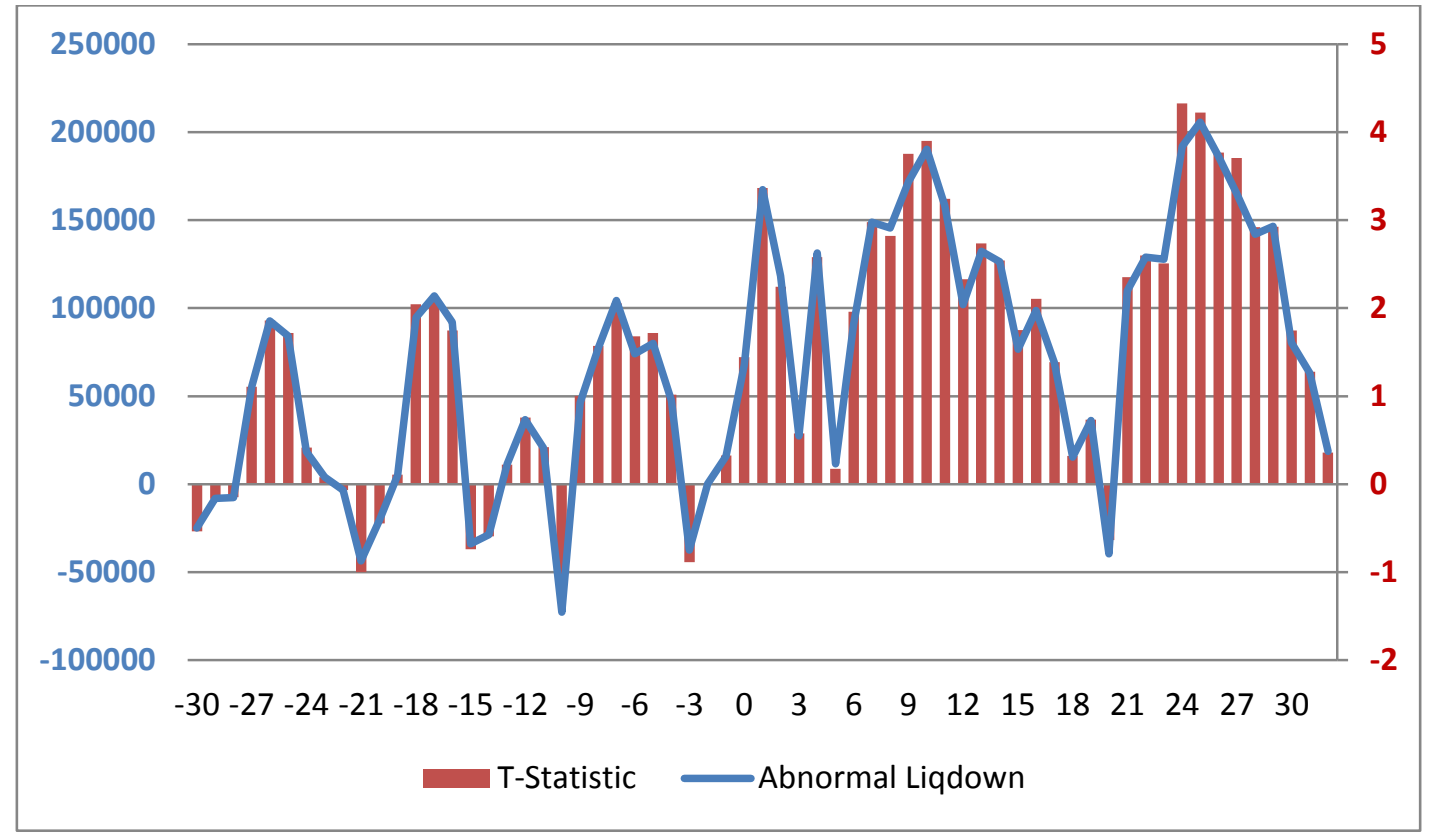

Figure 18: Acquiring Firm Liquidity

This figure shows Abnormal Liquidity for acquiring firms during the event period. The sample consists of 137 acquiring firms that make an unanticipated takeover bid.

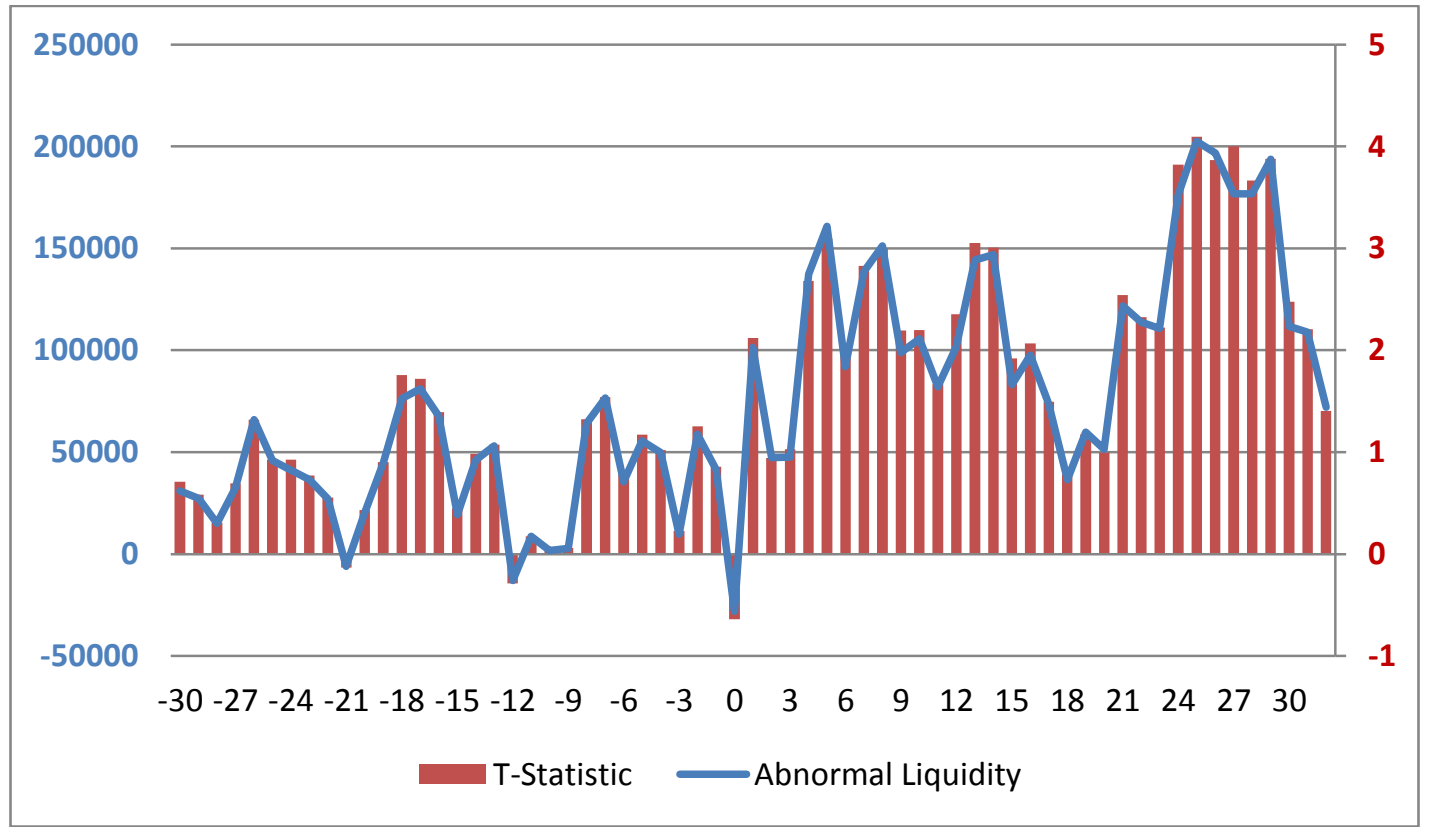


The insignificance of Liqdown during the pre announcement period causes Liquidity to also be insignificant during this same time horizon.

As detailed earlier, the significant negative abnormal returns on the announcement date explains the sharp decline in Liqup during the 10-12pm trading interval on the announcement day. However, the acquiring firm's share price decline results in a large number of buy orders, causing the significant abnormal increase in Liqdown during the $12-2 \mathrm{pm}$ and $2-4 \mathrm{pm}$ intervals on the announcement date. As a consequence, the bid announcement expands the depth of the bid-ask schedule. After the announcement date abnormal levels of Liqdown are observed during 18 of the 30 intervals in the post announcement period, perhaps due to arbitrageur's orders to cover their short positions in acquiring firm shares. However, more significantly, abnormal levels of Liqup are observed from interval +12 to the end of the post announcement period. The pessimistic nature of investors and the well documented long run negative return to acquiring firm shareholder's (see Loughran and Vijh (1997)) results in investors increasing the depth of the sell side of the order bookfor bidding firms. The combined effect of these abnormal increases in Liqup and Liqdown post announcement result in abnormal levels of liquidity to be observed in the post announcement period.

\subsection{Informed Trading Metric}

The results so far display abnormal increases in returns, volume and volatility during several intervals around the takeover announcement for target firms. A unique informed trading measure is examined in this section in order to infer whether these abnormal changes in returns, volume and volatility can be attributed to the existence of informed trading. If the informed trading metric is significantly greater than 0.5 , then this indicates that trade-initiating investors are achieving abnormal profits from their trading, assuming that investors close out their strategy on the specified reference date.

\section{Targets}

Figure 19 displays the results for this metric for target firms. The informed trading metric insignificantly fluctuates around its expected value throughout the event period; however a significant decrease is evident during and just after the announcement date.

Analysis of target firms shows that during the pre announcement period the informed trading metric is significantly below 0.5 on only one occasion,i.e., during interval -19 . Closer inspection of each component of the informed trading metric reveals that a large increase in the value of seller initiated losses is the cause of this behaviour. Further, Figure 20 shows that during the pre announcement period the cumulative informed trading metric (CITM) is negative and reaches a minimum of -0.35 . These results show that investors who implement trading strategies prior to the takeover announcement make losses. Thus, because investors on average are not making profits from their trading strategies prior to the announcement date and are selling target firm shares, rather than buying target firm shares, this provides 
evidence to suggest that consistent profitable informed trading is not occurring prior to takeover announcements.

The informed trading metric shows significant decreases during intervals +1 and +2 on the announcement date. This decrease on the announcement date can be attributed to both buyer and seller initiated losses, which suggests that investors who have purchased and sold target firm shares in order to profit from the announcement of takeover do so at prices unfavourable to the reference price. Similar findings are found during intervals $+3,+4,+6$ and +11 .

In sum, significant losses are made by trade-initiating investors immediately after the bid announcement. Further, although abnormal returns are made by the target firm during the pre announcement period, the evidence (on average) from the informed trading metric indicates that investors with information about the takeover bid are unable to consistently profit from it.

\section{Figure 19: Target Firm Informed Trading Metric}

This figure shows the Informed Trading Metric for target firms during the event period. The sample consists of 195 target firms that are the subject of an unanticipated takeover bid. A reference price occurring 20 trading days after the takeover announcement is used to calculate the Informed Trading metric.

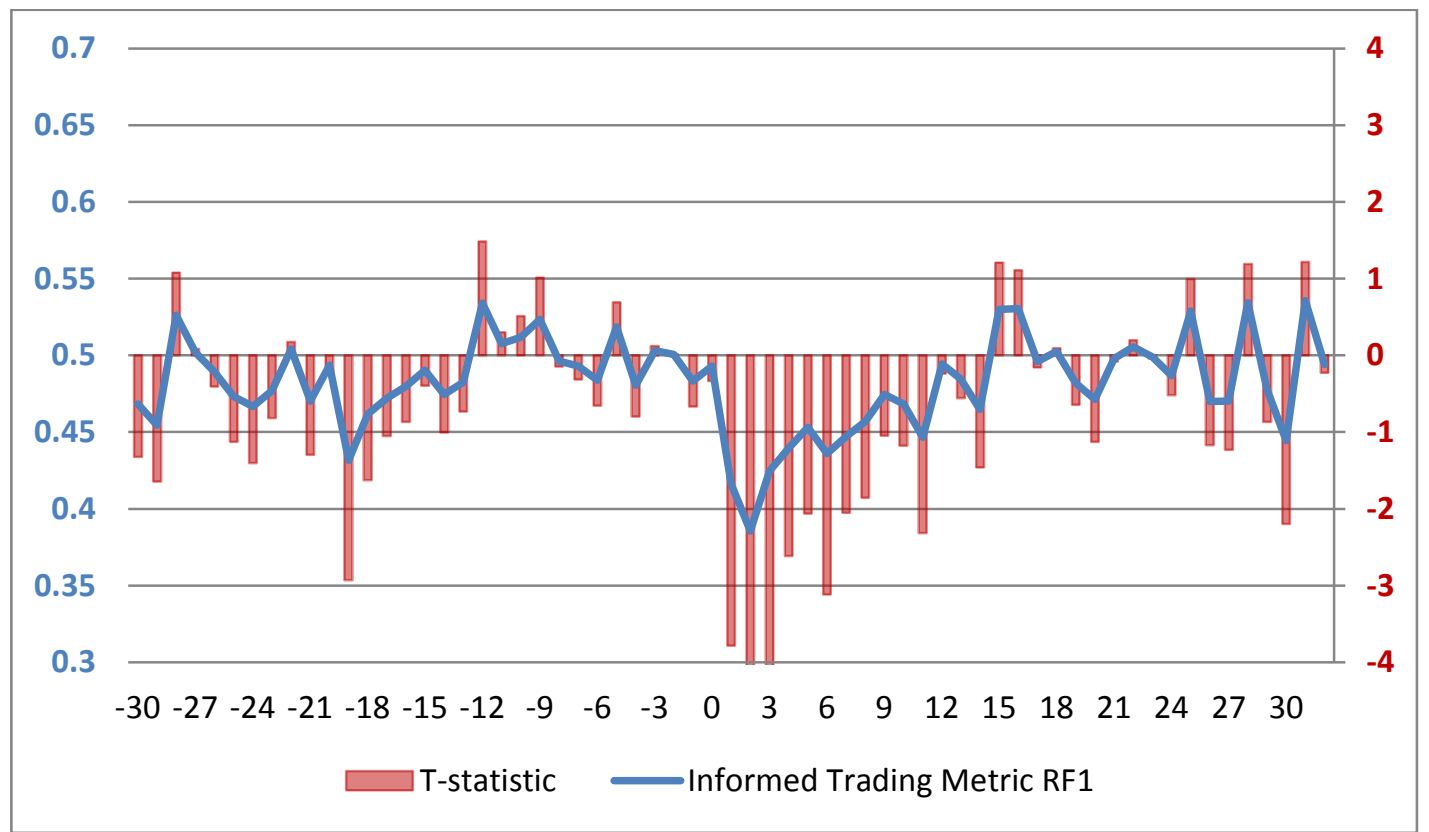




\section{Figure 20: Target Firm Cumulative Informed Trading Metric}

This figure shows the Cumulative Informed Trading Metric for target firms during the event period. The sample consists of 195 target firms that are the subject of an unanticipated takeover bid. A reference price occurring 20 trading days after the takeover announcement is used to calculate the Cumulative Informed Trading metric.

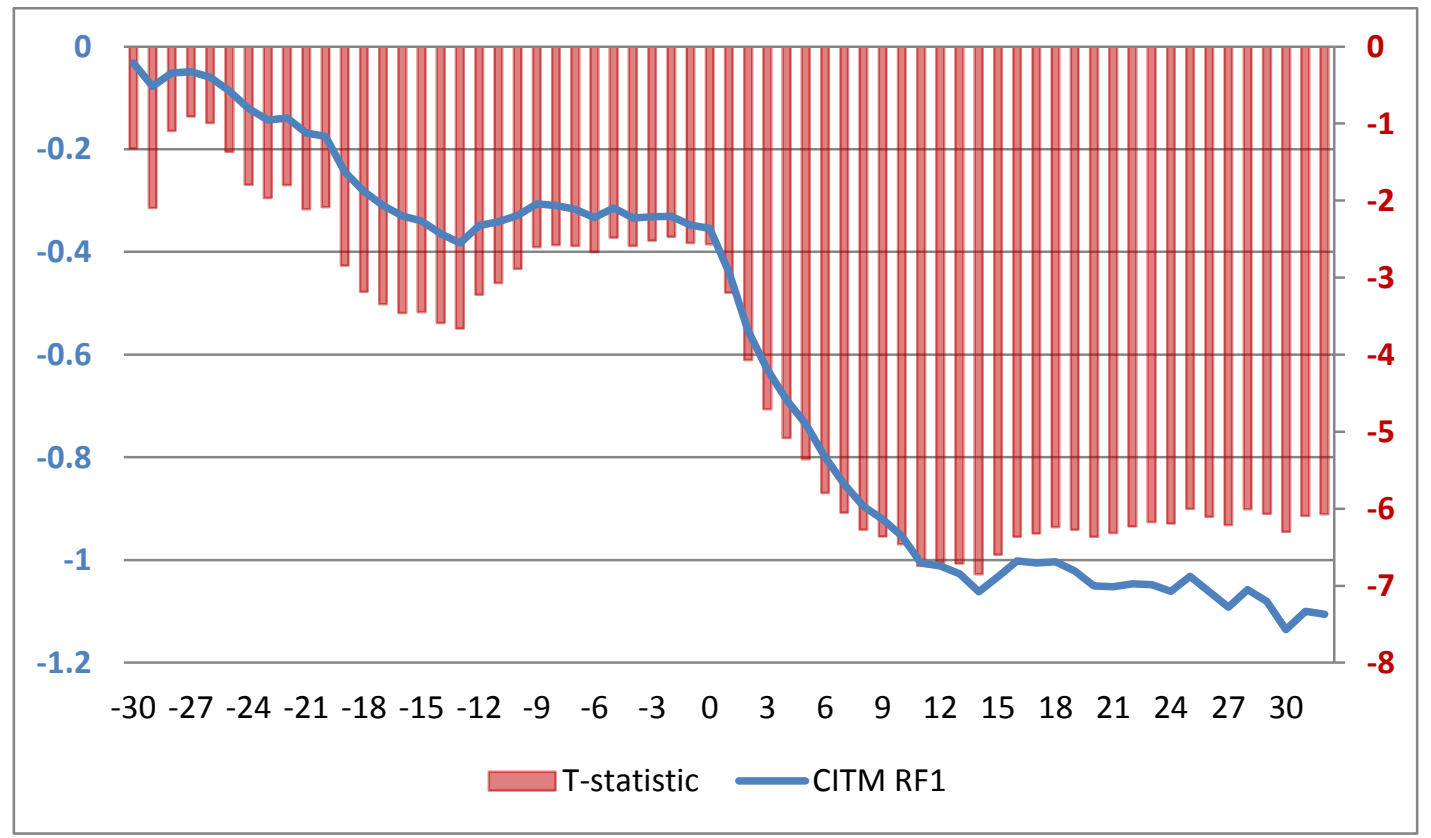

As an additional test, the relationship between cumulative pre bid abnormal VWAP returns and cumulative informed trading metric is explored in order to examine the existence of informed trading at a firm level. Table II presents the results of an OLS regression that finds a statistically significant positive relationship (t-statistic of 3.0301) between cumulative pre bid abnormal returns and informed trading. 
Table II

\section{Relationship between Cumulative Abnormal VWAP Returns and Cumulative Informed Trading} Metric

Table II presents the results of an OLS regression which uses the cumulative informed trading metric as the dependent variable and cumulative abnormal VWAP returns as the independent variable for 195 targets in Panel A and 141 Targets in Panel B. Both of these metrics are calculated at a firm level. Significance levels indicate: * $10 \%, * * 5 \%, * * * 1 \%$.

\begin{tabular}{cccc}
\hline PANEL A & Coefficient & Standard Error & T-Statistic \\
195 Targets & -2.6814 & 0.2716 & $-9.8734 * * *$ \\
\hline Intercept & 6.3207 & 2.0861 & $3.0301^{* * * *}$ \\
CAR & & 191 & \\
N & 0.0412 & \\
Adjusted $R^{2}$ & & $9.1814^{* * *}$ & \\
F-statistic & & Standard Error & T-Statistic \\
\hline PANEL B & Coefficient & 0.3394 & $-8.8627^{* * *}$ \\
141 Targets & -3.0081 & 2.4493 & $3.2882^{* * *}$ \\
\hline Intercept & 8.0537 & 141 & \\
CAR & & 0.0655 & \\
N & & $10.8122^{* * *}$ & \\
Adjusted $R^{2}$ & & & \\
F-statistic & & &
\end{tabular}

Further, Table III presents descriptive statistics for the distribution of the cumulative informed trading metric. The distribution for the 195 targets shows a large number of investors make a loss (CITM is less than 0.5) when trading around the takeover announcement. However, taking into consideration the positive relationship between pre bid abnormal returns and the cumulative informed trading metric, this distribution indicates that informed trading is evident for $18.5 \%$ of the 195 target firms examined in this study (i.e., CITM is greater than 0.5). Similar results are evident for the sub-sample of 141 targets where there is no toehold acquisition by the bidder. Again, the mean and median CITM measure are negative. However, 27 of these 141 targets (or 19.1\%) have a CITM measure greater than 0.5. These results perhaps alert the Australian Securities and Investments Commission (ASIC) that informed trading is seen reasonably frequently in the Australian takeover market. 


\section{Table III}

\section{Descriptive Statistics of Cumulative Informed Trading Metric}

Table III provides descriptive statistics of the cumulative informed trading metric (CITM) distribution at a firm level. Panel A lists the mean, median and decile distribution for 195 targets. Panel B lists the mean, median and decile distribution for 141 targets.

\begin{tabular}{lcc}
\hline & $\begin{array}{c}\text { Panel A } \\
\text { CITM 195 Targets }\end{array}$ & $\begin{array}{c}\text { Panel B } \\
\text { CITM 141 Targets }\end{array}$ \\
\hline Mean & -2.42 & -2.74 \\
Median & -2.02 & -2.08 \\
NOB > 0.5 & 36 & 27 \\
Decile Distribution & & \\
$0 \%$ (Minimum) & -13.29 & -15 \\
$10 \%$ & -8.22 & -8.48 \\
$20 \%$ & -4.98 & -5.54 \\
$30 \%$ & -3.78 & -4.23 \\
$40 \%$ & -2.84 & -2.84 \\
$50 \%$ & -2.02 & -2.08 \\
$60 \%$ & -0.90 & -1.21 \\
$70 \%$ & -0.24 & -0.29 \\
$80 \%$ & 0.41 & 0.43 \\
$90 \%$ & 1.22 & 1.22 \\
$100 \%$ (Maximum) & 6.52 & 6.07 \\
\hline
\end{tabular}

\section{Acquirers}

In this study two separate reference prices are used to determine whether investors are making abnormal profits by trading acquiring firm shares around takeover announcements. Evidence presented in Figures 21 and 22 (using reference price 2) suggests that informed traders who trade in the acquiring firms make a loss. In addition, the results obtained using reference price $3{ }^{18}$ indicates that informed traders similarly do not make significant profits or losses.

\footnotetext{
${ }^{18}$ These results are available on request.
} 


\section{Figure 21: Acquiring Firm Informed Trading Metric}

This figure shows the Informed Trading Metric for acquiring firms during the event period. The sample consists of 137 acquiring firms which make an unanticipated takeover bid. A reference price occurring 20 trading days after the takeover announcement is used to calculate the Informed Trading metric.

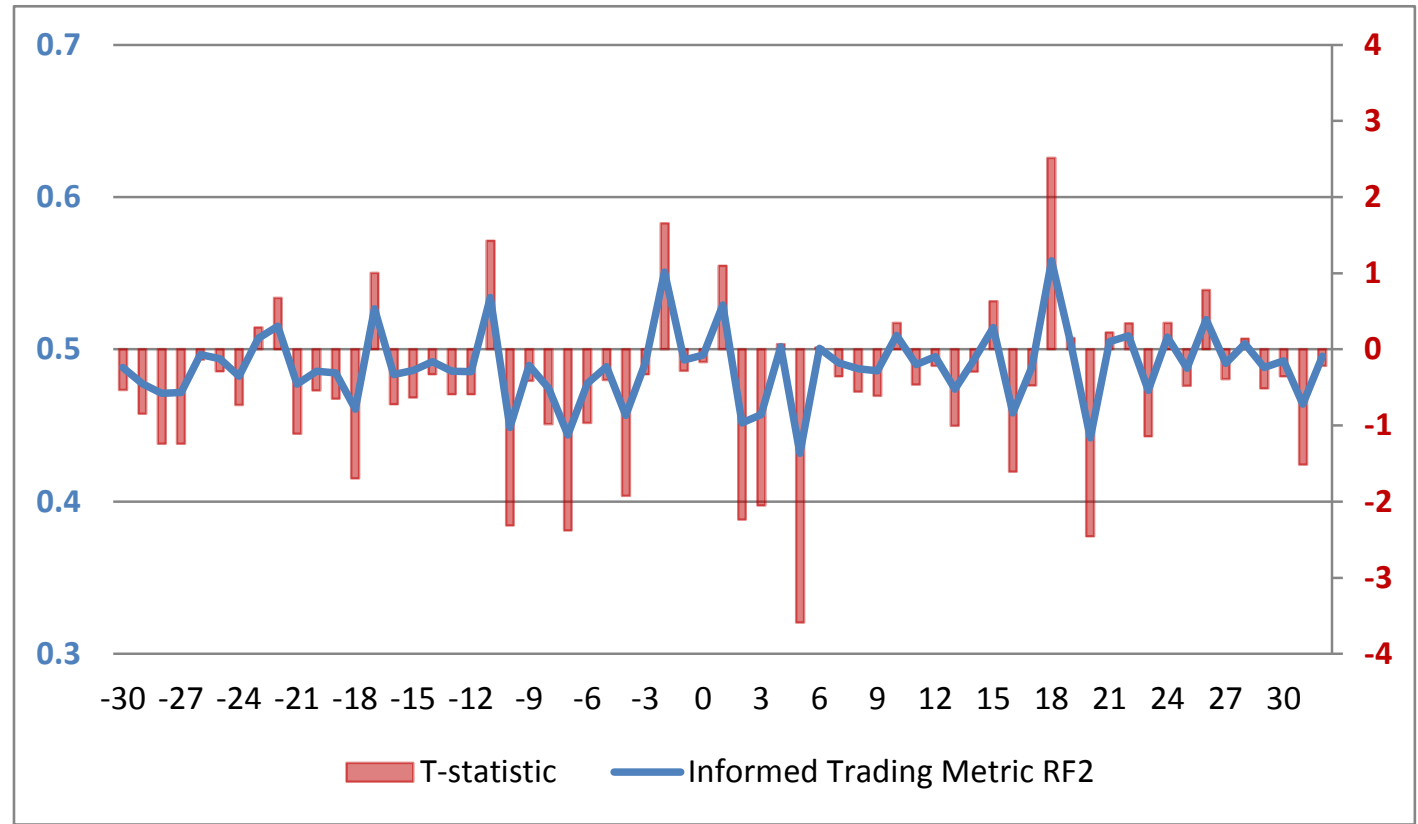

First, we analyse the informed trading metric for trade-initiating investors using a reference price 20 trading days after the public announcement of the bid. During the pre-announcement period the informed trading metric fluctuates below 0.5 , only during intervals -10 and -7 is it statistically significant.

These losses can be mainly attributed to buyer initiated losses. Further, during the 12-2pm session on the day before the announcement the informed trading metric increases to 0.55 . This occurs due to an increase in seller initiated profits as investors sell or go short in the acquiring firm prior to the announcement of the takeover. However, this finding provides limited evidence to suggest the existence of informed trading as it is not reliably different to 0.5 . After the announcement the informed trading metric is significantly less than 0.5 during intervals +5 and +20 due to buyer and seller initiated losses respectively. Throughout the entire event period investors only make significant profits during interval +18 , in which investors profit by buying acquiring firm shares at prices below the reference price. Using reference price 2 , the evidence reveals six negative and only one positive significant informed trading value during the entire event period. This result indicates that trade initiators in bidder-firm shares do not seem to win. 
Figure 22: Acquiring Firm Cumulative Informed Trading Metric

This figure shows the Cumulative Informed Trading Metric for acquiring firms during the event period. The sample consists of 137 acquiring firms which make an unanticipated takeover bid. A reference price occurring 20 trading days after the takeover announcement is used to calculate the Cumulative Informed Trading metric.

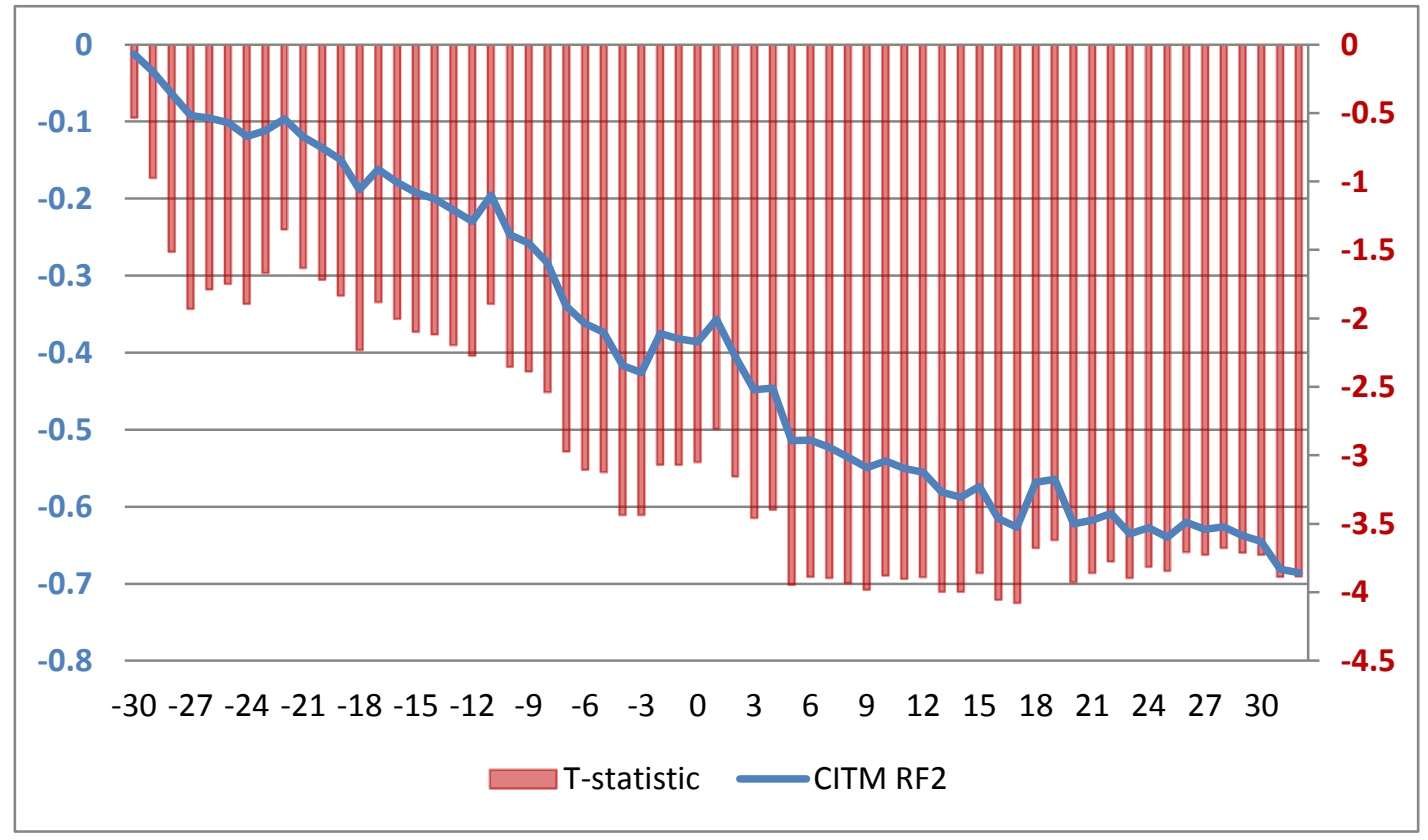

In addition a reference price occurring 250 trading days after the takeover announcement is also used to calculate a longer-term informed trading metric. This reference date was selected with the aim of ensuring that the effect of the takeover announcement and subsequent negotiations and revisions was fully revealed in the reference price. The results using reference price 3 are generally insignificant (only one tstatistic for the informed trading measure, in interval +18 , is greater than 2.0 , and there are no cumulative informed trading values that are significant) and indicate that on average investors do not make significant profits or losses. Accordingly, these results are not reported in detailed figures.

\section{Conclusion}

This study shows evidence of abnormal returns, volume, volatility, bid ask spreads and bid side depth during the pre announcement period for target firms and thus suggests that informed trading occurs in these firms. Further, abnormal behavior is observed on the announcement date for all of these metrics as investors trade on news of the takeover announcement. As news of the takeover bid becomes incorporated 
into the target firm's share price the abnormal behaviour of these metrics diminishes over the post announcement period.

In addition, limited evidence of informed trading in acquiring firms is found in documented abnormal decreases in returns, increases in volume, widened spreads and increased selling of acquiring firm shares

prior to the takeover announcement. Similarly, on the announcement date we observe significant negative returns, increases in volume, spreads and liquidity as investor's trade on the announcement of the takeover. During the post announcement period abnormal levels of volume, spreads and liquidity exist due to uncertainty of whether the bid will succeed, whether the bid will be revised and whether a competing bid will be made.

The results of a unique informed trading metric show on average that informed traders who trade in either the target or acquiring firm during the event period make a loss. More importantly perhaps, when this metric is analysed at a firm level, evidence of informed trading is found in approximately $10-15 \%$ of target firms. Further, the results presented within this paper are robust to different subsamples and both parametric and non parametric statistical testing.

In essence, this study finds evidence to suggest that informed trading is reasonably prevalent within the Australian market. These results should provide an indication to ASIC that whilst current regulation is relatively successful in reducing informed trading for the full sample of targets, more stringent surveillance might be required to further reduce information asymmetries in someAustralian takeover targets.

In order to improve the explanatory power of the results in this paper, further research should look to determine whether the levels of informed trading documented in this paper can be attributed to insider trading, i.e., corporate representatives of the target or acquiring firm. In addition, further research could examine option trades made around the announcement date. For example, due to the leverage advantages of out-of-the money call options, it can be expected that informed traders would take long positions in call options issued on the target firm. 


\section{References}

Ascioglu, N.A., McInish, T.H., Wood, R.A., 2002. Merger announcements and trading. The Journal of Financial Research 25, 263-278.

Betton, S., Eckbo, B.E., 2000. Toeholds bid, jumps, expected payoffs in takeovers. The The Review of Financial Studies 13, 841-882.

Bradley, M., 1980. Interfirm tender offers and the market for corporate control. Journal of Business 53, 345-376.

Bradley, M., Desai, A., Kim, E.H., 1988. Synergistic gains from corporate acquisitions and their division between the stockholders of target and acquiring firms. Journal of Financial Economics 21, 4-40.

Brock, W.A., Kleidon, A.W., 1992. Periodic market closure and trading volume. Journal of Economic Dynamics and Control 16, 451-489.

Brockman, P., Chung, D.Y., 1999. Bid-ask spread components in an order-driven environment. Journal of Financial Research 22, 227-246.

Brown, P., da Silva Rosa, R., 1998. Research method and the long-run performance of acquiring firms. Australian Journal of Management 23, 23-38.

Casey, R., Dodd, P., Dolan, P., 1987. Takeovers and corporate raiders: empirical evidence from extended event studies. Australian Journal of Management 12 201-220.

Chiyachantana, C.N., Jiang, C.X., Taechapiroontong, N., Wood, R.A., 2004. The impact of regulation fair disclosure on information asymmetry and trading: an intraday analysis. The Financial Review 39, 549-577.

Clarkson, P.M., Joyce, D., Tutticci, I., 2006. Market reaction to takeover rumour in internet discussion sites. Accounting and Finance 46, 31-52.

Conrad, J., Niden, C.M., 1992. Order flow, trading costs and corporate acquisition announcements. Financial Management 21, 22-31.

Copeland, T.E., Galai, D., 1983. Information effects on the bid-ask spread. The Journal of Finance 38, 1457-1469.

Corporations and Markets Advisory Committee, 2003. Insider Trading Report. Available at http://www.camac.gov.au/camac/camac.nsf/byHeadline/PDFFinal+Reports+2003/\$file/Insider_T rading_Report_Nov03.pdf

Cotter, J.F., Zenner, M., 1994. How managerial wealth affects the tender offer process. Journal of Financial Economics 35, 63-97.

Cumming, D., Li, D., 2010. Runup of acquirer stock in public and private acquisitions. Working Paper, York University.

Dodd, P., 1976. Company takeovers and the Australian equity market. Australian Journal of Management 1, 15-35.

Draper, P., Paudyal, K., 1999. Corporate takeovers: mode of payment, returns and trading activity. Journal of Business Finance \& Accounting 26, 521-558.

Duong, T.H.H., Izan, H.Y., 2008. Consequences of riding takeover waves: Australian evidence. Working Paper, University of Western Australia.

Easley, D., O'Hara, M., 1987. Price, trade size, and information in securities markets. Journal of Financial Economics 19, 69-90.

Easley, D., Kiefer, N., O'Hara, M., Paperman, J.,1996. Liquidity, information, and infrequently traded stocks. Journal of Finance 51, 1405-1436.

Eyssell, T.H., Arshadi, N., 1993. Insiders, outsiders, or trend chasers? An investigation of pre-takeover transactions in the shares of target firms. The Journal of Financial Research 16, 49-59. 
Foster, D.F., Vishwanathan, S., 1993. Variations in trading volume, return volatility and trading costs: evidence on recent price formation models. The Journal of Finance 48, 187-211.

Foster, D.F., Vishwanathan, S., 1995. Trading costs of target firms in corporate takeovers. Advances in Financial Economics 1, 37-59.

George, T.J., Kaul, G., Nimalendran, M., 1991. Estimation of the bid-ask spread and its components: a new approach. The Review of Financial Studies 4, 623-656.

Glosten, L.R., 1994. Equilibrium in an electronic open limit order book. The Journal of Finance 49, 11271161.

Glosten, L.R., Harris, L.E., 1988. Estimating the components of the bid/ask spread. Journal of Financial Economics 21, 123-142.

Huang, R.D., Stoll, H.R., 1997. The components of the bid-ask spread: a general approach. The Review of Financial Studies 10, 996-1034.

Jarrell, G.A., Poulsen, A.B., 1989. Stock trading before the annoucement of tender offers: insider trading or market anticipation. Journal of Law: Economics, and Organization 5, 225-248.

Jarrell, G.A., Brickley, J.A., Netter, J.M., 1988. The market for corporate control: the empirical evidence since 1980. The Journal of Economic Perspectives 2, 49-68.XXXXXXX

Jennings, R., 1994. Intraday Changes in Target Firms' Share Price and Bid-Ask Quotes Around Takeover Announcements. The Journal of Financial Research 17, 255-270.

Jennings, R.H., Mazzeo, M.A., 1993. Competing Bids, Target Management Resistance, and the Structure of Takeover Bids. The Review of Financial Studies 6, 883-909.

Jensen, M.C., Ruback, R.S., 1983. The Market For Coporate Control: The Scientific Evidence. Journal of Financial Economics 11, 5-50.

Keown, A.J., Pinkerton, J.M., 1981. Merger Announcements and Insider Trading Activity: An Empirical Investigation. The Journal of Finance 36, 855-869.

Kim, S.H., Ogden, J.P., 1996. Determinants of the Components of the Bid-Ask Spread on Stocks. European Financial Management 1, 127-145.

Kryzanowski, L., Lazrak, S., 2007. Trading Activity, Trade Costs and Informed Trading for Acquisition Targets and Acquirers. The European Journal of Finance 13, 405-439.

Kyle, A.S., 1985. Continuous Auctions and Insider Trading. Econometrica 53, 1035-1064.

Lin, J., Sanger, G.C., Booth, G.G., 1995. Trade Size and Components of the Bid Ask Spread. The Review of Financial Studies 8, 1153-1183.

Lipson, M.L., Mortal, S., 2006. Liquidity and Firm Characteristics: Evidence from Mergers and Acquisitions. Working Paper, University of Virginia and Missouri.

Loughran, T., Vijh, A.M.,1997. Do Long-Term Shareholders Benefit from Corporate Acquisitions? The Journal of Finance 52, 1765-1790.

Madhavan, A., Richardson, M., Roomans, M., 1997. Why do Security Prices Change? A Transaction Level Analysis of NYSE Stocks. The Review of Financial Studies 10, 1035-1064.

McInish, T.H., Wood, R.A., 1992. An Analysis of Intraday Patterns in Bid/Ask Spreads for NYSE Stocks. The Journal of Finance 47, 753-764.

Meulbroek, L.K., 1992. An Empirical Analysis of Illegal Insider Trading. The Journal of Finance 47, 1661-1699.

Murray, P.G., 1994. Pre-Announcement Share Price Run-Ups and Abnormal Trading Volume in Takeover Target's Shares: A Test of the Market Speculation Hypothesis. Pacific-Basin Finance Journal 2, 319-348. 
Sanders, R.W., Zdanowicz, J. S., 1992. Target Firm Abnormal Returns and Trading Volume Around the Initiation of Change in Control Transactions. Journal of Financial and Quantitative Analysis 27, 109-129.

Stoll, H.R., 1989. Inferring the Components of the Bid-Ask Spread: Theory and Empirical Tests. The Journal of Finance 44, 115-134.

Walter, T.S., 1984. Australian Takeovers: Capital Market Efficiency and Shareholder Risk and Return. Australian Journal of Management 9, 63-118. 